\title{
Documenting the Social: Frank Scholten Taxonomising Identity in British Mandate Palestine
}

\author{
Sary Zananiri
}

Frank Scholten, a Dutchman and photographer, travelled to Palestine in 1921, staying a little over two years. The wealth of photographs he produced provides us with a particular insight into the vast changes the country was experiencing in the aftermath of World War I and the fall of the Ottoman Empire. His documentary style of photography, and his project to produce an illustrated Bible, demonstrates a complicated confluence of religious narrative and modern scientific methodologies, as well as post-Ottoman and European approaches to social organisation. Both the Scholten Collection ${ }^{1}$ and the man himself are significantly understudied. In attempting to understand Scholten's unique approach to photography, attention must be paid to his background as well as the social and political context of early British Mandate Palestine to fully grasp the taxonomies he employed.

Scholten, much like the complicated body of photographs he left behind, defies typical categorisations given the ways he approached the imaging of Palestine. Scholten's lens gives us a rare insight into Palestine society from elites to villagers. He captures ethno-confessional diversity as well as the significant shifts taking place in the early 1920s. The many contradictions that he and his work embody, makes for a very particular lens through which to view the social histories of the establishment of the British Mandate in Palestine, showing a collision of more typical readings dealing with the Biblical past against the modern life which such imaging typically effaces.

In attempting to map Scholten's photographic outputs and methodology, we need to take into account the complexity of the milieu with which he was associated in Europe, the cultural contexts into which he was born and lived

1 The Frank Scholten Collection was closed to the public for many years. It is currently in the process of being digitised, catalogued and made publicly available for the first time. Given the collection's transitional period, where references are made to boxes, they are from the older pre-catalogue system that will soon be defunct. Image references are from the new incoming system. 
as well as the complicated set of materials he both collected and produced in his study of Palestine.

This complexity beckons several questions. How did Scholten's background as a member of the Dutch elite, a Catholic convert and a homosexual colour his approach to understanding the diversity of Palestine from an ethnoconfessional and class perspective? What role did contemporary networks of scholarship play in shaping his complex approach to Palestine? And, most importantly, what can the collision of modern ${ }^{2}$ scholarly approaches and Biblical narrative in his photographs tell us about the effects of the enormous social changes on the many communities in Palestine?

This chapter will first discuss Scholten's background before considering the scholarly methodologies and contexts with which he was engaged and implicated. It will then consider and compare the social context in both Palestine and Europe, leading to an examination of selected works from the Scholten Collection.

\section{Frank Scholten}

Frank Scholten, who was born in 1881 and died in 1942, lived through a period of transition that bridged two worlds. His class background and education cemented his elite status within Dutch society, but we can suppose, from his familial rifts, ${ }^{3}$ his homosexuality and its related legal transgressions, ${ }^{4}$ he was also an outsider.

Coming from a well-to-do family with links to the Dutch aristocracy, ${ }^{5}$ the commercial necessities of photographic practice can be seen as playing little part in guiding Scholten's lens, making him free of the commercial demands

2 Modern here is defined as the product of industrialisation, in cultural terms and in line with the sociological definition proffered by Anthony Giddens, The Consequences of Modernity (Cambridge: Polity Press, 1991): 1-21.

3 For instance, he left home shortly after his father's death and, later, a series of exchanges between Scholten and his step-mother in the wake of the stock market crash in 1929 show the turbulence of familial relations, see Teresa Lidia Kwiecien,, "Frank Scholten", Depth of Field 40 (December 2008). https://depthoffield.universiteitleiden.nl/2540fo5en/. Accessed February 22, 2020.

4 Theo van der Meer, Jonkheer mr. Jacob Anton Schorer (1866-1957): Een biografie van homoseksualiteit (Amsterdam: Schorer Boeken, 2007), 159-63.

5 His father, grandfather and great-grandfather had been among the top officials of the Dutch investment bank Nachenius Tjeenk and his mother was a 'jonkvrouw', an honorific title denoting nobility. See van der Meer, Jonkheer mr. Jacob Anton Schorer (1866-1957), 162 and Kwiecień, "Frank Scholten." 
of the photographic market that most professional photographers dealt with. Estimates of the Scholten Collection that is currently being catalogued sit around twelve thousand printed photographs and fourteen thousand negatives alongside a significant body of images, ephemera and books that he collected as well as his postcard correspondence, mostly with his friend Geertje Pooyar. The photographs taken by Scholten appear to start from the late World War I period in The Netherlands, to images of his travels through Germany, Italy and Greece in 1920 to the more than two years he spent in Palestine from 1921 to $23,{ }^{6}$ which comprise the bulk of the collection. There are also smaller collections of images from France, the UK and other parts of Europe, presumably taken when he later returned to Europe.

When Scholten died in 1942 from later complications related to a car accident, he left this array of material to the Netherlands Institute for the Near East (NINO). Alongside this was his library, a collection of 'found images' including photographs, postcards, prints and images clipped from books, and other assorted ephemera. These found images were annotated and generally pasted to boards in line with contemporary practices of archiving photographs of art historical subjects. He also left notes towards a 16-volume set of photo books titled 'Palestine Illustrated'7 only two of which were published (though in four language editions), and a sum of money to continue the production of his unpublished work, for which he left behind some notes and arrangements of images.

As a photographer, Scholten took a documentary approach, and one that was, at least in Palestine, high in output. The photographic collections he left behind show a diverse array of local subjects and geographies including cities, towns, villages, the countryside and the desert. In his time in Palestine, he travelled the country extensively, as well as trips to Lebanon, Syria and Jordan. He

6 Kwiecień, "Frank Scholten".

7 For details of Scholten's various editions see: François Scholten, La Palestine Illustrée: Tableau Complet de la Terre Sainte par la Photographie, Évoquant les Souvenirs de la Bible, du Talmud et du Coran, et se rapportant au passé comme au présent, Vol I La porte d'entrée - Jaffa Vol II.Jaffa la Belle (Paris: Jean Budry \& Co., 1929). German: Frank Scholten, Palästina - Bibel, Talmud, Koran. Eine vollständige Darstellung aller Textstellen in eigenen künstlerischen Aufnahmen aus Gegenwart und Vergangenheit des Heiligen Landes. Bd. I: DIE EINGANGSPFORTE. JAFFA. Mit 449 Abbildungen in Kupfertiefdruck, Bd. II:JAFFA, DIE SCHÖNE. Mit 371 Abbildungen in Kupfertiefdruck (Stuttgart: Hoffmann, 1930). English: Frank Scholten and G. Robinson Lees, eds., Palestine Illustrated including References to Passages Illustrated in the Bible, the Talmud and the Koran, Vol.1 Gate of Entrance, Vol.2Jaffa the Beautiful (London: Green Longmans, 1931) and Dutch: Frank Scholten, Palestina: Bijbel, Talmud, Koran. Een volledige illustratie van alle teksten door middel van eigen artistieke foto's uit het heden en verleden van het Heilige Land De toegangspoortJaffa (Leiden: Sijthoff, 1935). 


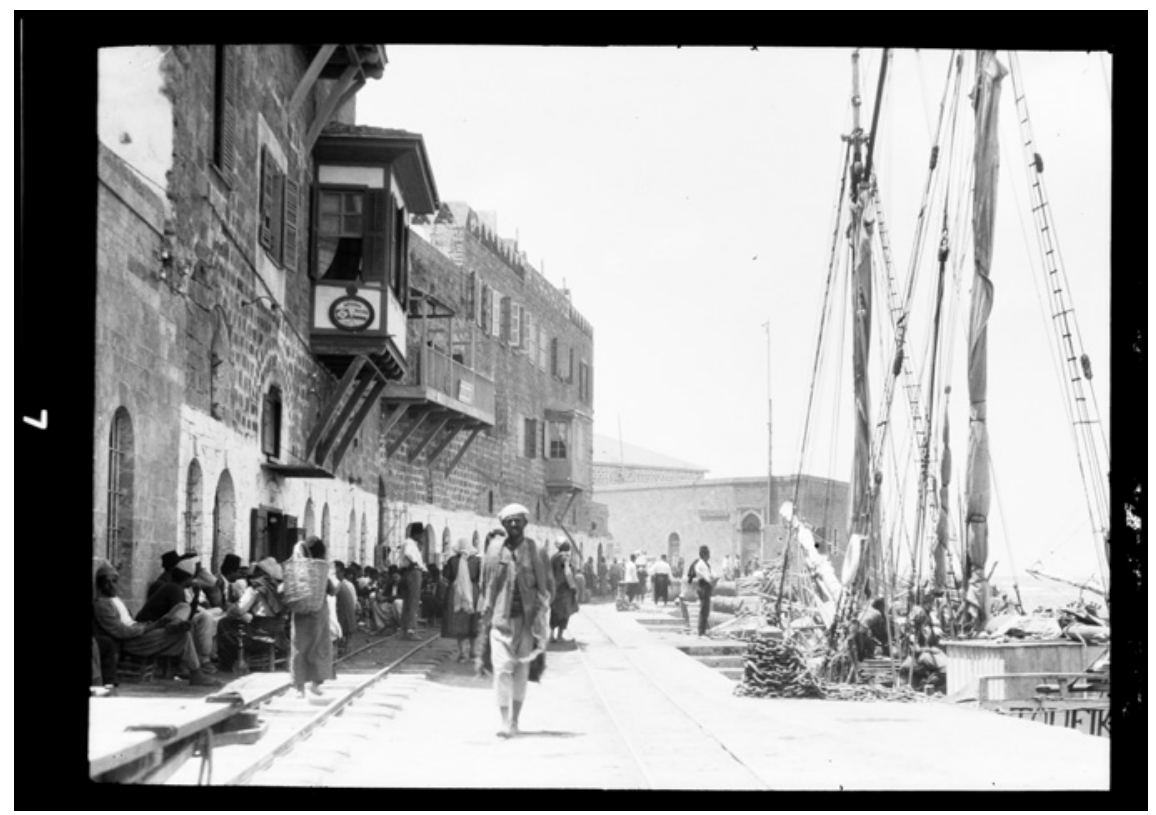

FIGURE 8.1 Untitled, 1921-23. Frank Scholten. Jaffa Port. Digitised negative. Frank Scholten. UBL_NINO_F_Scholten_Jaffa_o6_oo48, Frank Scholten Collection IMAGE COURTESY OF NINO AND UBL

photographed people, archaeology, sites of religious significance, urban streetscapes and rural villages, domestic interiors, social and religious events, the new colonial networks that the incoming British Mandate brought with it, and the early days of Tel Aviv, still in its infancy in the early 1920 .

Scholten's background was in many ways fundamental to the lens through which he viewed Palestine. Born to a wealthy Protestant family, Scholten converted to Catholicism before travelling to Palestine, ${ }^{8}$ though evidence of exactly when the conversion took place has yet to be found.

In the Netherlands, the social system of pillarisation ${ }^{9}$ broke society into confessional and political spheres having wide ranging consequences from the provision of health and educational structures to which media outlets communities engaged with. Scholten's conversion perhaps points the particular

8 In a postcard to his friend Geertje dated 16th January, 1920 Scholten talks of attending confession and taking communion at St Peters in Rome. I would like to thank Lara van der Hammen for her translation of some of the postcards. Frank Scholten Collection, Box E2.

9 Harry Post, Pillarization: An analysis of Dutch and Belgian society (Aldershot [etc.]: Avebury, 1989). 
sensitivity towards similar structures of Ottoman Millet system, which had been reshaped significantly during the Empire's nineteenth century Tanzimat Reforms, that were still very much in place, though beginning to morph, at the beginning of the British Mandate.

After growing up in Amsterdam, he received a liberal education in Berlin around the turn of the twentieth century. ${ }^{10}$ In this time spent between his native Netherlands and Berlin's bohemian milieu, Scholten was brought into contact with the social and political world of the early homosexual emancipation movement. He is known to have stayed in Berlin with the famous German sexologist Magnus Hirschfeld." Berlin had become a place known for its sexual openness. ${ }^{12}$ Scholten also frequented the working-class area of De Pijp in Amsterdam, the setting for Jacob Israël de Haan's openly gay novel Pijpelijntjes (1904), ${ }^{13}$ which was similarly colourful.

In 1920, he left The Netherlands amidst legal charges related to his activities that involved soliciting young military men on trains and at Amsterdam's Central station (Fig. 8.14). He was subsequently charged with two years jail in absentia. ${ }^{14}$ In its first year, his travels took him to Italy, Greece, Germany and Switzerland. Within his collected images we see works of art from antiquity, the Renaissance and modern works, which reflect his wide art historical interests and support the idea of an anachronistic Grand Tour of sorts. A number of smaller photo albums from this period underscore his documentary style, showing a mixture of street scenes with portraits of people he encountered..$^{15}$

The second part of his journey, continuing onwards to Palestine, might be seen as more in line with ideas of a pilgrimage, perhaps with a redemptive tone given his legal predicaments at home. He had a significant library of six

10 Kwiecień, "Frank Scholten".

11 Van der Meer, Jonkheer mr. Jacob Anton Schorer (1866-1957), 215.

12 Robert Deam Tobin quotes an aristocratic client of British sexologist Havelock Ellis who had travelled extensively suggesting that Berlin was "more extensive, freer and easier than anywhere else in the Orient or Occident", which makes an interesting point of comparison to someone like Scholten. R. Deam Tobin, Peripheral Desires: The German Discovery of Sex (Philadelphia: University of Pennsylvania Press, 2015), 1.

13 J. Haan and W. Simons, Pijpelijntjes (Amsterdam: Van Cleef, 1904).

14 Jos van Waterschoot, Bert Sliggers, and Marita Mathijsen, Onder De Toonbank: Pornografie En Erotica in De Nederlanden (Amsterdam: Uitgeverij van Oorschot, 2018), 172-173.

15 Of the 12 boxes of photographs, photographic albums and negatives produced by Scholten, only two in the UBL collection deals with European images, although another two have recently been found in the NINO (The Netherlands Institute for Near East) stores which contain mixture of photographs Scholten took in Europe and postcards he collected. These will be amalgamated with the broader collection at UBL. 
thousand books with him in Palestine,$^{16}$ from which we can suppose that he had planned his photographic project in advance.

Both Scholten as a figure and the material he left behind, raise important questions about his singular view of Palestine. Given his employment of complicated taxonomies, how did he approach the imaging of Palestine? How did his identity and his milieu, scholarly or otherwise, influence these taxonomies? By what means did he relate Biblical narrative to the modern life he encountered and imaged in Palestine?

One might be tempted to ascribe the term amateur to Scholten's photographic practice, given his lack of commercial investment more typical of 'Holy Land' genres of photography. Despite this, it is perhaps more fitting to see him as harking back to earlier modes of being, such as the aristocratic scholar-gentleman of the Enlightenment or the devotee of classical antiquity, given his time in Italy and Greece and some of the materials he had collected. In this regard, the scholarly overtones of the collection make for an interesting foil to those of the École biblique discussed by Karène Sanchez Summerer and Norig Neveu in their chapter on the Dominican photo library. ${ }^{17}$

In this light, we might look to art historical methodologies of the day to contextualise Scholten's practice. Much of found images - those images he collected - are pasted to cardboard, reference their source and a Biblical quotation relevant to the image, place or event depicted, and were left in various states of preparation.

Though the collection is currently being catalogued by the photography department in special collection at Leiden University Library (UBL), the methodology is typical of art historical approaches of the late nineteenth century and early twentieth century, in which source images were pasted to board, carefully labelled, taxonomised and organised into folders.

Through the current cataloguing project, it has become evident that much of the collected images were in a process of being sorted. Several categories emerge. The first are those images that have been pasted to card, with a

\footnotetext{
16 Kwiecień, "Frank Scholten".

17 Several postcards from Scholten to his friend Geertje Pooyar in Volendam mention social and professional interactions with the Dominicans during his time in Palestine. While it is hard to gauge the extent of relations from a series of postcards, it would seem that Scholten's pedagogical approach may have reflected the Dominicans' approach to presenting photography as a kind of evidence. Frank Scholten Collection, Box E2.
} 
reference to their source be it a book or an individual and a Biblical quote (which is sometimes also appended with a particular translation of the Bible). The second category is unpasted, and just a clipping, with either a Bible quotation, a reference to its source or both. The third category is other images that have been clipped from various locations that are not appended at all. This third category of material typically consists of smaller images that are of a less interesting quality. It would seem that as Scholten was collecting and processing these found images he either never completed the process or disregarded the third category as rejects.

A good point of comparison, both culturally and chronologically, might be the German Kunsthistorisches Institut in Florenz (KHI) established in 1897, which consists of a photographic archive of Italian artworks that range from antiquity to the modern era, taxonomised by material, era and location. The KHI Collection both parallels the period which Scholten was producing his own archive, as well as providing an insight into Northern European approaches to the Mediterranean. The KHI Collection comprises of photographs of artworks that were pasted onto card, which were then appended with the title of the artwork depicted in the photograph, the date the photograph was taken, the name of the photographer as well as other relevant information about the artwork. These 'plates' were then taxonomised by geography and period of the artwork depicted, then stored in boxes, forming the core of the KHI archive.

In a postcard dated 3rd May, 1922, written from Jerusalem to his friend Geertje in the Netherlands, Scholten wrote 'These days I'm preparing to leave again; gluing pics, writing letters and making visits.' ${ }^{18}$ It is unclear whether this postcard is in reference to the found images he was collecting or the photographs he was producing, that exist as loose photographs, photographs pasted to card and photographs pasted into albums. Another postcard to Geertje sent

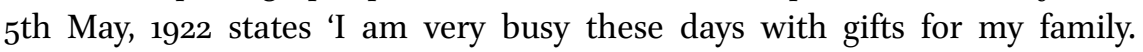
Photographs (24 pieces each) for my grandmother in Amsterdam, for my mother, for my three aunts, for my uncle and for my two sisters. So much family! This would perhaps indicate working on his own photographs, rather than found images, and may explain some of the more eclectic albums in the collection, such as the series he titled Choses Intéressante ('Interesting Things').

Within Scholten's photographic corpus, there is a numbering system that occurs within sections of his loose photographs pasted to card and the albums (though not seemingly the unpasted loose images). Punctuating the loose images pasted to card are other cards without photographs that have numbers applied to them with some sort of letter transfer technique (Fig. 8.2). This

18 Postcard to Geertje, Frank Scholten Legacy collection, Frank Scholten Collection, Box A2. 


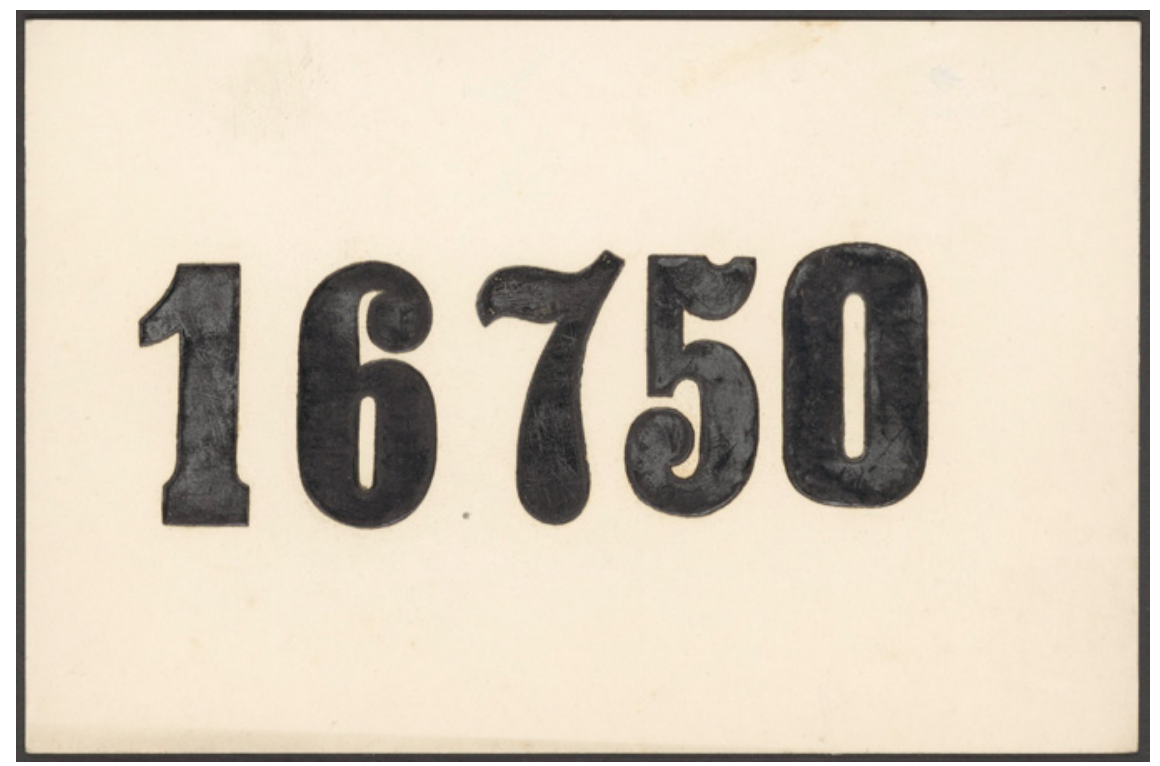

FIGURE 8.2 Cardboard divider with letter transfers. UBL_NINO_F_Scholten_Fotos_ Doos_07_0285. Frank Scholten Collection IMAGE COURTESY OF NINO AND UBL

would hint that at some stage there an order to the collection that appears to correlate to several ledgers, but sadly with the multiple moves of the collection, this order appears to have been lost and would constitute a very significant project to reinstate.

Among the textual references he made on the found images and cards to which they were pasted, and indeed in the books he published, were references to different translations of the Bible from the Vulgate by Glaire and Vigouroux in French to Martini's La Sacra Bibbia in Italian to the Greiner Bibel in German. This textual approach to the Bible also shows scholarly engagement with the theological, particularly textual criticism and 'the quest for the historical Jesus, ${ }^{\prime 19}$ which had been a growing field in the late nineteenth and early twentieth century.

Alongside these references were many more references to interpretive texts dealing with the Bible, Biblical history and the history of Palestine. Many of

19 Albert Schweitzer's book of the same name, published in German in 1910, capitalised on this interest and attempted to study the various historical approaches to the life of Jesus. See Albert Schweitzer, trans. W. Montgomery, The Quest for the Historical Jesus: A Critical Study of its Progress from Reimarus to Wrede (London: Adam and Charles Black, 1911): 21. 
these were also illustrated, giving him a good knowledge of the visual vocabularies used to depict Palestine and the 'Holy Land in Western authored photos'.

Scholten's methodology of taxonomisation was likely developed during time spent in Berlin, both during his studies and afterwards. Such methodologies show a nuanced understanding of scholarly, art historical methodologies and at least a working, if not broader, knowledge of theological debate, particularly around textual criticism and Biblical history.

Within the German context, Scholten spent with Magnus Hirschfeld, the German physician, sexologist and founder of the Humanitarian Scientific Committee, an organisation dedicated to advocating for the rights of sexual minorities. In 1910, Scholten was staying with Hirschfeld, likely through introduction by the early gay rights activist Jacob Schorer, who founded of the Dutch chapter of the Humanitarian Scientific Committee. ${ }^{20}$ At that time, Hirschfeld had just published Die Transvestiten, ${ }^{21}$ one of the early studies on transvestites and cross-dressing. Contemporary critiques of the work notwithstanding, it was a significant landmark that for the first time attempted to taxonomise gender and sexuality in the emergent science of sexology. ${ }^{22}$ The milieu which Scholten inhabited in Europe, points towards an engagement with the cutting-edge academic research methodologies of the day, that focused on the categorisation and taxonomisation of identity. It is possible that Scholten derived the ethnographic taxonomies that he employed in his published volumes partially from Hirschfeld's own explorations of sexual and gender taxonomy.

We see the complexities of confessional, ethnic, class and cultural demarcations that show the early Mandate as a period in which the cosmopolitanism of Ottoman legacies was overlayed with an incoming European milieu, both Jewish and Christian (Fig 8.3). Through the course of the Mandate period, nationalist narratives would come to solidify nationalist projects culturally, politically and physically, and indeed cement the newly created national borders, as it did elsewhere in the former empire, ${ }^{23}$ effectively undermining the complexity of ethnic, national, confessional and class dimensions that had

$20 \quad$ Van der Meer, Jonkheer mr. Jacob Anton Schorer (1866-1957), 171-176.

21 Magnus Hirschfeld, The Transvestites, trans. M.A. Lombardi cited in text; Magnus Hirschfeld, "Die intersexuelle Konstitution Zwischenstufen": 23 cited in: Darryl B. Hill, "Sexuality and Gender in Hirschfeld's Die Transvestiten: A Case of the "Elusive Evidence of the Ordinary", Journal of the History of Sexuality 14, no. 3 (2005): 316-332; https://www .jstor.org/stable/3704656, accessed February 22, 2020.

22 Hill, "Sexuality and Gender in Hirschfeld's Die Transvestiten", 316.

23 Prescient examples in the north of the former Ottoman Empire are the Armenian genocide or the so-called 'population exchanges' between Greece and Turkey in considering the broader context and effects of rising nationalism, both of which were roughly contemporaneous to Scholten's period of travel. 


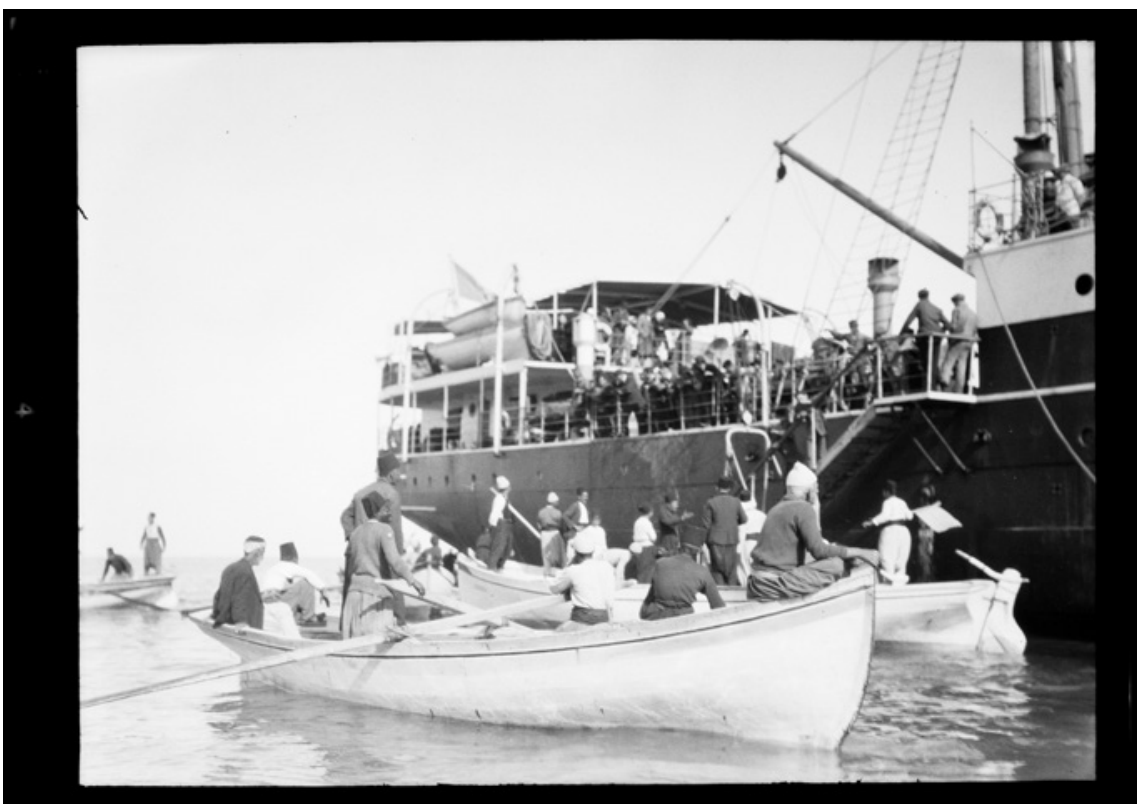

FIGURE 8.3 Untitled, 1921-23. Frank Scholten. A ship arriving in the Port of Jaffa. Digitised negative. UBL_NINO_F_Scholten_Jaffa_16_ooo8, Frank Scholten Collection IMAGE COURTESY OF NINO AND UBL

developed through the late Ottoman period and into the opening years of the British Mandate.

The amorphous political and cultural possibilities posed for Palestinians by the ailing Ottoman Empire in the early twentieth century and during World War I gave rise to significant political debates within indigenous communities. ${ }^{24}$ Firstly, in whether to support the Ottomans or the Allies during the war and secondly, with respect to Zionist immigration and the British support for it. Alongside, and linked to such political debate, was the context of the Nahda (the 'awakening' or 'Arab Renaissance'), the cultural renewal that underpinned Arab nationalism and occurred slightly later in Palestine's smaller cities than larger centres like Beirut or Cairo. With the beginning of the British Mandate there were new certainties in terms of peace and post war redevelopment, but also new uncertainties with regards to Zionism and its support by the British that coloured the period. While Palestinian nationalism had certainly

24 For a good summary of some of these debates, see Ihsan Salih Turjman and Salim Tamari, Year of the locust: A Soldier's Diary and the Erasure of Palestine's Ottoman Past (Berkley: University of California Press, 2015). 
pre-dated the British Mandate, ${ }^{25}$ as had Zionism, ${ }^{26}$ the cultural structures the British Mandate created would exacerbate and cement difference, particularly through language policy, ${ }^{27}$ strongly honing identity formation processes into categories of 'Arab' and 'Jew' and effectively erasing the complex and intricate cultural identifications (and their legislated support structure) of the Ottoman era.

Given the political and cultural context of the 1910s and 20s, we see much of this tumult playing out in the Scholten collection, particularly in the inventory of ethno-confessional taxonomies Scholten employed.

A brief inventory of the taxonomies Scholten employed in the captioning of his photographs includes Greek-Orthodox, Catholic, Melkite, Protestant, Muslim and Jewish Palestinians; German, Russian, Spanish, Hungarian, Romanian, Moroccan, Iranian, Bukharan and other Arab Jewish communities; British, French, German, Greek, Russian and Italian Europeans, as well as Americans, and also Egyptians, Sudanese, Indians and Nepalese reflective of the incoming colonial administration and its networks. Scholten also attends to class divides within many of these cultural and confessional taxonomic designations that, within the rubric of Ottoman social structures, also indicates an understanding of urban-rural divides.

\section{Modern Forces: Taxonomy and Transnational Social Contexts}

\subsection{From Pillar to Millet}

While we can deduce, from the scholarly networks he inhabited, how Scholten was engaged and influenced by a number of disciplines and the methodologies which they produced, another way of framing his work and practice is through the ways he connected the social contexts within which he functioned on a macro level. These social frameworks demonstrate transnational connections, whether through systems of social formation, contexts surrounding issues of language or the vocabularies of visual culture. These macro level social systems

25 See, for instance, the hostility towards Zionism in the Arabic press before the First World War. Emanuel Beška, From Ambivalence to Hostility: The Arabic Newspaper Filasțīn And Zionism, 1911-1914 (Slovak Academic Press: Bratislava, 2016).

26 The First Zionist Congress was held in August 1897 which established what would become the World Zionist Organization.

27 This can be seen in the support of Hebrew as part of British language policy in Palestine despite its initial marginality during the period of revival. See for instance Andrea L. Stanton, “This Is Jerusalem Calling': State Radio in Mandate Palestine", Journal of Palestine Studies 47, no 2 (2018): 13-14. 
can be seen as operating in tandem with scholarly discourses in his output, but separating them in framing Scholten's output gives us an insight into the broader social and historical forces that were formative in shaping his world view.

The context of Verzuiling, literally 'compartmentalisation' in Dutch, but known as pillarisation in English, was a key concept for understanding the social formations of Dutch society from the late nineteenth century until the 196 os. $^{28}$ Dutch pillarisation created four primary socio-political groupings: a Catholic, Protestant, liberal and socialist pillars. ${ }^{29}$

For Scholten, growing up in the last decades of the nineteenth century, he would have witnessed the establishment and growing influence of Abraham Kuyper's Anti-Revolutionary Party (ARP), a neo-Calvinist organisation that would eventually see Kuyper as Prime Minister from 1901-05. ${ }^{30}$ Kuyper was instrumental in the formalisation of pillarisation.

There are several scholarly interpretations behind the rise of the pillarisation. Firstly, pillarisation as a means of 'emancipation' within the context of class politics in socialist pillar, the 'kleyne luden' (small people) of the middleand working-class Protestant pillar, and the subordination of Catholics by the Protestant kingdom, each of which sat against the liberal pillar, drawn primarily from the upper classes. Secondly, as a confessional safeguarding around the processes of secularisation with the rise of modern forces in the nineteenth century. Thirdly, as a means of cementing the status of elites internally within each pillar. And finally, given emergence of pillars from the mid nineteenth century set against the backdrop of industrialisation and technological innovation, there is an argument that the apparatus of modernity enabled the opportunity, for the first time, to organise larger scale networks of supra-local organisations. ${ }^{31}$ Without delving into the debates beyond the scope of this paper, it is clear that modernity had a significant role in codifying pillarisation in the Netherlands, and with it, the population itself.

While it is important to stress that agreement on the universal totality of pillarisation in compartmentalising Dutch communities is divided on how intensely its effects were felt and experienced, suffice it to say the system certainly mediated much of historical social life from media like newspapers and magazines to social and leisure associations, education including

28 James D. Bratt, Abraham Kuyper: Modern Calvinist, Christian Democrat. 2nd Impression (Grand Rapids, Michigan: Eerdmans Library of Religious Biography, 2013): 343 .

29 Staf Hellemans, "Pillarization ('Verzuiling'). On Organized 'Self-Contained Worlds' in the Modern World", The American Sociologist, 51 (2020): 125.

30 James D. Bratt, Abraham Kuyper, xxiii-xxviii.

31 Hellemans, Pillarization, 130. 
universities, welfare and philanthropic endeavours, and even unions and other professional associations.

In this regard, Scholten's conversion to Catholicism probably also negotiated a distinct social shift personally. Certainly the correspondence between him and his friend Geertje who lived in Volendam gives a significant sense of the extensive Catholic networks through which Scholten operated in Palestine, from social contact with the Dominicans of École biblique to patronising institutions like Notre Dame to his links indigenous Catholic communities across class boundaries.

One of the more significant considerations that elements of Scholten's background, his arrival in Palestine and the social shifts his conversion may have engendered, is comparison to the complexities of Ottoman communalism. The Millet system that had been in place since the Ottoman conquest of Constantinople in 1453, but had undergone significant reforms in the second half of the nineteenth century, ${ }^{32}$ paralleling the emergence of pillarisation in the The Netherlands.

In 1856, Sultân 'Abd al-Majīd I affirmed the equal status of Muslim and nonMuslim Ottoman subjects alike. This constituted a significant shift in policy from the protected, but subordinate status of dhimmi with the jizya, extra taxes payed by members of such millets. ${ }^{33}$ Alongside this, a number of new millets, or pillars as they might have been identified by the Dutch Scholten, were added through the course of the nineteenth century, mainly in reference to specific denominations of Christianity. Nonetheless, the shift in status from dhimmi to citizen had a broader political utility in the administration of the Empire, particularly in addressing the developing political affinities that derived from the intervention and protection of smaller non-Muslim communities by the European powers. ${ }^{34}$

The nature of the broader context of shifting political regimes in early Mandate Palestine would create 'minorities' (within a Western nation state framework) from communities that had historically been millets within the Ottoman Imperial framework, ${ }^{35}$ adding yet more complexity to ways we must

32 Karen Barkey and George Gavrilis, "The Ottoman Millet System: Non-Territorial Autonomy and its Contemporary Legacy", Ethnopolitics 15, no. 1 (2016): 24-42.

33 Heather Sharkey, "History Rhymes? Late Ottoman Millets and Post-Ottoman Minorities in the Middle East", International Journal of Middle East Studies 50, no. 4 (2018): 76o-761.

34 For more information on such cultural diplomacy and its effects on Christian communities, see Karène Sanchez Summerer and Sary Zananiri, eds., European Cultural Diplomacy and Arab Christians in Palestine, 1918-1948. Between Contention and Connection (London: Palgrave Macmillan, 2021).

Sharkey, History Rhymes?, 76o-764. 
understand early 1920 Palestine. This however underscores the emerging shifts of identity formation processes in the period.

There is no direct evidence of how Scholten understood either the Millet system or pillarisation. However, as the various taxonomies outlined at the end of the previous section of this chapter attest, Scholten was very attentive to the complicated social context of post-Ottoman Palestine in his various designations. This demonstrates at least a perception of communitarian difference. The context of pillarisation and, in Scholten's case, its transgression, may partially explain, in combination with his scholarly engagements, his complex use of taxonomies within the complex communal nature of recently postOttoman Palestine.

\subsection{Transnational and Transcommunal Concerns}

The significant collection of found images that Scholten collected, shows an interest in Biblical narrative, the classical world, Renaissance art and architecture, religious art, Orientalist imaging as well as the works of photographers, illustrators and printmakers vested in the depiction of Palestine and the Biblical. In piecing together the relationship of these found images and the photographs Scholten took during his years in Palestine, we can see an attempt to frame the complex social life he found in Palestine. The materials he collected range in production date from the 185 os to the late 193 os and deal with significantly longer chronology in the artworks they depict, from the ancient to the modern. While the range of images largely deal with Palestine, the Bible or Biblical history, sometimes in oblique ways, certain themes can be detected that link seemingly disparate areas of Scholten's interests. One such theme is repeated collections of the Biblical figure of David, from image reproductions of Michelangelo's masterpiece ${ }^{36}$ to Arnold Zadikow's ${ }^{37}$ modernist rendition to clippings from religious books and illustrated bibles, including several that show David's relationship to Jonathan (Fig. 8.17). ${ }^{38}$

This Biblical material and images of Palestine sits alongside other, much smaller, categories such as satirical cartoons commenting on Dutch politics of the day, socialist posters and other assorted political materials. Such material may have been of personal political interest, but also reflect interest in other

36 Along with many other artists of the Renaissance, Michelangelo's married classical Greco-Roman sculptural aesthetics with Christian narrative.

37 Arnold Zadikow was a German-Jewish modernist sculpturer. Incidentally, he is also known to have produced Magnus Hirschfeld's headstone.

38 The ambiguities of the relationship between David and Jonathan, the son of Saul, were often used to justify homosexual relations theologically. Interestingly, Oscar Wilde quoted this as part of his defence during his infamous trial for homosexuality. See https://www .famous-trials.com/wilde/327-home, accessed February 22, 2020 . 
pillars within the Dutch social system. However, when read in combination Scholten's proximity to the Humanitarian Scientific Committee and his 'queering' of religious imagery - point to at least some consideration of questions of social justice, both temporal and spiritual. A complex picture of Scholten's perspective begins to emerge around the rubrics of religion, sexuality and art history, particularly when intersected with broader social context. Borrowing from various scholarly disciplines, the taxonomical principles he applies to his photography in Palestine attempts to synthesise something that approaches an anthropological study from images of a diversity of people to religious events, like Nabī Mūsā, which was itself undergoing rapid changes from a religious to a nationalist festival in this period (Figs. 8.4 and 8.5). ${ }^{39}$

After his return to Europe, Scholten held his only exhibition, Palestine in Transition in London's Brook Street Gallery from 25th to 29th February, 1924. It was organised under the auspices of the Anglo-Palestinian Club, ${ }^{40}$ a Zionist organisation that had been founded two years earlier. ${ }^{41}$ It would seem that Scholten viewed his exhibition more as an opportunity for progressing his career or Catholic interests, rather than a position of political partisanship given attitudes relayed in his postcards to Geertje. On the 25th July, 1922, in the aftermath of the British White Paper ${ }^{42}$ Scholten wrote 'Arrived in Jerusalem yesterday evening, to avoid that Jewish Feast in Tel Aviv. I did not want to toast (champagne) to the health of the Jews, and on their possession of the $\mathrm{H}$. Land. That is why I dodged it'.43

Confessional concerns seem to be at the core of Scholten's aims for the exhibition: 'They object to those Catholic texts, but I am not moved to put them in a Protestant way. I'd prefer not exhibit'.44 What it does underscore, however, is the development of a Zionist cultural diplomacy, particularly in the UK where it served to capitalise on Zionist-Protestant affinities and the political gains made with the Balfour Declaration, just seven years earlier. The exhibition comprised of around 2,00o photographs. Sadly, either no catalogue was

Awad Halaby, "Islamic Ritual and Palestinian Nationalism: al-Hajj Amin and the Prophet Moses Festival in Jerusalem, 1921 to 1936," in Jerusalem Interrupted:Modernity and Colonial Transformation 1917-Present, ed. Lena Jayyusi (Northampton, MA: Interlink Publishing: 2013), 139-152.

40 The British Journal of Photography, February 29, 1924, 130.

41 William Rubinstein and Michael Jolles, The Palgrave Dictionary of Anglo-Jewish History (London: Palgrave MacMillan UK, 2011), 69.

The White Paper was written by the then Secretary of the State for the Colonies, Winston Churchill and released on 3rd June, 1922. Postcard to Geertje 16th February, 1924, Frank Scholten Collection, Box E2. 

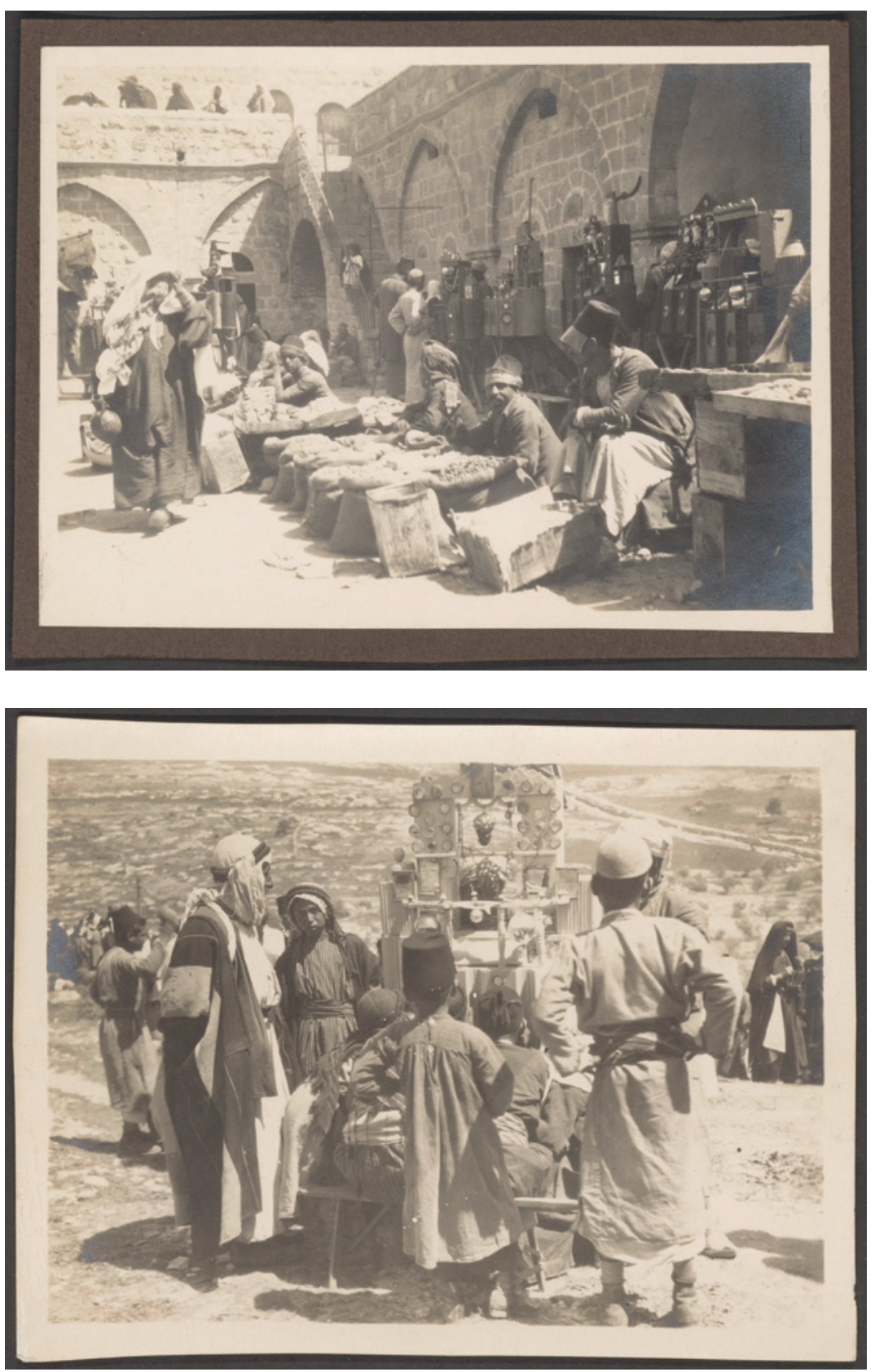

FIGURES 8.4 AND 8.5

Jour Nabī Mūsā and Untitled (also Nabī Mūsā), 1921-23. Frank Scholten, UBL_NINO_F_Scholten_Fotos_Doos_O2_OO71 and UBL_NINO_F_Scholten_Fotos_Doos_O2_OO72. Frank Scholten Collection

IMAGES COURTESY OF NINO AND UBL 
produced or it has been lost. ${ }^{45}$ The exhibition, however, received positive reviews from the British press, both Jewish and non-Jewish, for showing the nature of modernity in the ancient 'Holy Land. ${ }^{46}$

\subsection{Towards the Biblical Moderne}

By the time Scholten had arrived in Palestine a Western scholarly culture had developed. A number of permanent institutes had been established such as École Biblique et Archéologique Française de Jérusalem (189o), the American School of Oriental Study (1900) and British School of Archaeology in Jerusalem (1919). These archaeological institutions by their very nature were, of course, more vested in the ancient past - often in Biblical terms - rather than the present moment, but each were attempting to employ new scholarly methodologies, including the use of photography, in dealing with archaeology in Palestine.

The institutionalisation and reassessment of biblification, both in Scholten's corpus and elsewhere, and the attempt to reconcile Biblical interest with that of modern, scientific methodology, is what we might term the Biblical Moderne. ${ }^{47}$ The Biblical Moderne represents a rupture in biblified representation that either consciously or unconsciously attempted to build on, correct and legitimise previous generations of imaging by reconciling them with modern scholarly approaches, a concept that looms large in the methodological approaches that Scholten employed in his work.

On the one hand, Scholten is clearly cognisant of his Christian, and specifically Catholic, positioning given the majority of the titles he referenced. ${ }^{48}$ His attempts to mediate a position denotes a somewhat liberal and inclusive subject position that we can presume was drawn from the formative cultural context he had inhabited in Europe. On the other hand, he also adopts a problematic assumption of scholarly objectivity under the auspices of the scientific, which can be seen in the centring of Christianity in the quotation of Christian,

45 I tried to trace a catalogue at the British Library and National Arts Library. While I found numerous catalogues from the Brook Street Gallery in the same period, it appears that one was not published for what was only a one-week exhibition.

46 There were a number of reviews of the exhibition, these include The British Journal of Photography, February 29, 1924; “Life in Palestine”; Times (London, England) 26 Feb. 1924, 5; The Times Digital Archive. Web. 28 Sept. 2018; The Universe The Catholic Newspaper, February 29th, 1924.

47 I would like to thank Stephen Sheehi for suggesting this useful term in feedback on this chapter during the conference that led to this publication.

48 A full inventory has yet to be made, but the titles he references and the sources of found images indicate that he had a significant library on the topics of Palestine, biblical history and theology. 
Muslim and Jewish scriptures in his two published volumes, the notation of his found images and the notes towards the other 14 volumes.

Published in four different language editions ${ }^{49}$ (French, German, English and only the first volume of two in Dutch), the images maintain uniformity across each imprint, but the emphasis on quotations shift slightly in each language. It is worth noting that the differences between the various language editions often paralleled the relationships of those language speakers to the communities he was photographing in Palestine. This could show a nuanced understanding of colonial geo-politics in each of the language markets he addressed or may simply be marketing machinery to different groups of European-language speakers. In either case, the catering to a particular language market with slightly more sources from their respective tongues belies the colonial relations and cultural affinities that had developed in the Ottoman era and into the British Mandate.

Though it has to be said they are only very slight differences, the French edition (1929), for example, has extra quotations for Catholic, Armenian and Sephardic communities; the German (1930) emphasis on German Templars, Protestants and Ashkenazis; the English (1931) a similar focus to the German, but with a few more evangelical references. The Dutch edition, of which only one volume was published, is slightly harder to compare, but does reference a number of Dutch works on Christianity that the others do not. ${ }^{50}$

The fact that the images remain uniform across all four language editions, ${ }^{51}$ hints that either he regarded the image as having a universal value or that he regarded the images - as informal and intimate as they often are - as a form of ethnographic data collection for his project for which text was regarded as secondary evidence. If this is the case, it would constitute an interesting inversion of biblified imaging practices, in which the primacy of Biblical text was typically used to read the 'Holy Land'. Instead, we could position Scholten as prioritising the primacy of the image over the quotations to which he had ascribed them. This again hints at a certain focus on modern scientific methodologies influenced by the taxonomies above, but also at the same time reinforces the sanctity of the land, still positioning it within some rubric of biblification. The reconciliation of the Biblical and scientific is perhaps where we might place Scholten's work within the trope of the Biblical Moderne.

49 It seems a Spanish edition was also proposed, but never produced, see postcard to Geertje 13th May, 1931, Frank Scholten Collection, Box E2.

50 Sary Zananiri, "Frank Scholten: Landschap in het Brits Mandaat Palestina", Fotografisch Geheugen 96 (December 2018).

51 There is however a printing error in one edition, where the pages are out of sequence, however the images were clearly marked with the same numbers as the other editions. 


\section{Modernity, Orientalism and Biblification: Applying Taxonomies to Scholten in Palestine}

The process of remediating Palestine and Palestinians in photography for western circulation networks, as many chapters of this volume attest, was primarily focused on the use of the Biblical to interpret what might otherwise have been seen as a 'foreign' world. The familiarity of the Biblical, both as a textual narrative and, by the early 1920s, as a familiar imaging trope, relied on bridging a gap between the western consumer of such images and the otherness of the so-called 'Orient' through the construction of a Western Biblical imaginary. Biblification, as Issam Nassar terms it, actively highlighted the Biblical narrative, remediating modern Palestine to an ancient past in a process that excised (Palestinian) modernity.52 In many ways, this is a stark contrast to Scholten's approach, which, as the title of his 1924 exhibition Palestine in Transition implied, depicted a place undergoing rapid changes brought about by modernity.

\subsection{Class and Urban-Rural Divides}

Western photographers producing work for a Western audience had predominantly concerned themselves with the Biblical, while local photographers focused on a mixture of production for local consumption, be it through the commissioning of studio portraits, carte de visite, ${ }^{53}$ documenting events for the state, religious authorities, the media and academia, as well as similar biblified production as their western counterparts for a similar western market. ${ }^{54}$ Scholten is a rarity in terms of visiting photographers, in that he photographed

$5^{2}$ For a more detailed discussion and definition of biblification see: Issam Nassar, "Biblification' in the Service of Colonialism: Jerusalem in Nineteenth-century Photography", Third Text 20, no. 374 (2006): 317-326; Issam Nassar, "Colonization by Imagination", in City of Collision, eds. P. Misselwitz, T. Rieniets, Z. Efrat, R. Khamaisi and R. Nasrallah (Basel: Birkhäuser, 2006); Issam Nassar, European Portrayals of Jerusalem: Religious Fascinations and Colonialist Imaginations (Lewiston, NY: Edwin Mellen Press, 2006).

53 A useful chapter that frames the social and ideological implications of studio portraiture and specifically the phenomenon of the carte de visite in the Arab World until 1910 is Stephen Sheehi's chapter, "The Carte de Visite: The Sociability of New Men and Women", in his book The Arab Imago: A Social History of Portrait Photography 1860-19ro (Princeton: Princeton University Press, 2016), 53-74.

54 For instance, see the photographic outputs of Khalil Ra'ad from his photographs of World War I commissioned by the Ottomans, Salim Tamari, "The War Photography of Khalil Raad: Ottoman Modernity and the Biblical Gaze", Jerusalem Quarterly $5^{2}$ (2013): 25-37, to works that specifically focus on the biblical see images from his catalogue in chapter 6 of this volume. 
portraits of local people, both elites as well as those from more humble backgrounds, making the collection of specific importance to garnering an overview of the rapid shifts taking place in the early 1920 .

To contextualise the importance of Scholten's corpus, we might turn our attention to the British Mandate's various urban planning policies, as Nadi Abusaada has written in his chapter.Jerusalem, as many other cities, was changing rapidly, even with the early urban planning schemes developed by William McLean and Charles Ashbee, which progressively removed the nineteenth and early twentieth century urban growth abutting the Old City Walls in Jerusalem to quite physically separate the Old City, with its all its religious connotations, from its suburban surroundings. ${ }^{55}$ This demonstrates a very physical iteration biblification of the Old City and its environs, prosecuted within romanticism of the British Arts and Crafts movement of which Ashbee was an adherent. On the other hand, the taxonomies employed by British planners paid little attention to Palestinian villages on the urban peripheries that grew into some of the most well-built sections of the new city. As Rana Barakat points out, they were regarded as rural and hence outside of British taxonomies of either ancient or modern, ${ }^{56}$ but were also disregarded within demographic studies of the city, ${ }^{57}$ showing the erasure of semi-rural Palestinian communities on the urban periphery, even on a bureaucratic level by ignoring the category altogether.

Based on looking at Scholten's corpus broadly, it would be fair to say that the majority of photographs he took were documentary in nature. They are generally not staged when in public space. Although he certainly made portraits of people, even in these posed contexts they tend towards the casual snapshot, rather than the more formal language and conventions of studio photography. It is important to conceive of Scholten's photographic practice as one which purveys a relative naturalism, if not one which frames a particularised perspective, but there are indeed still limitations to how we might contextualise Scholten's interactions.

In an article in the Dutch press dated April, 1934, Scholten described how he managed relations, particularly with rural communities. This ranged from pleasantries and platitudes, to an incident where Scholten worked with his chauffeur to get a photograph of a shepherd. His chauffeur suggested that if a shepherd didn't have his photograph taken, a war with Mussolini in Italy might

55 Roberto Mazza, Jerusalem from the Ottomans to the British (London: I.B. Tauris, 2009).

$5^{6}$ Rana Barakat, "Urban planning, colonialism and the Pro-Jerusalem Society," Jerusalem Quarterly 65 (Spring 2017): 32.

57 Rana Barakat, "The Jerusalem Fellah: Popular Politics in Mandate-Era Palestine," Journal of Palestine Studies vol. 46, no. 1 (Autumn 2016): 9. 


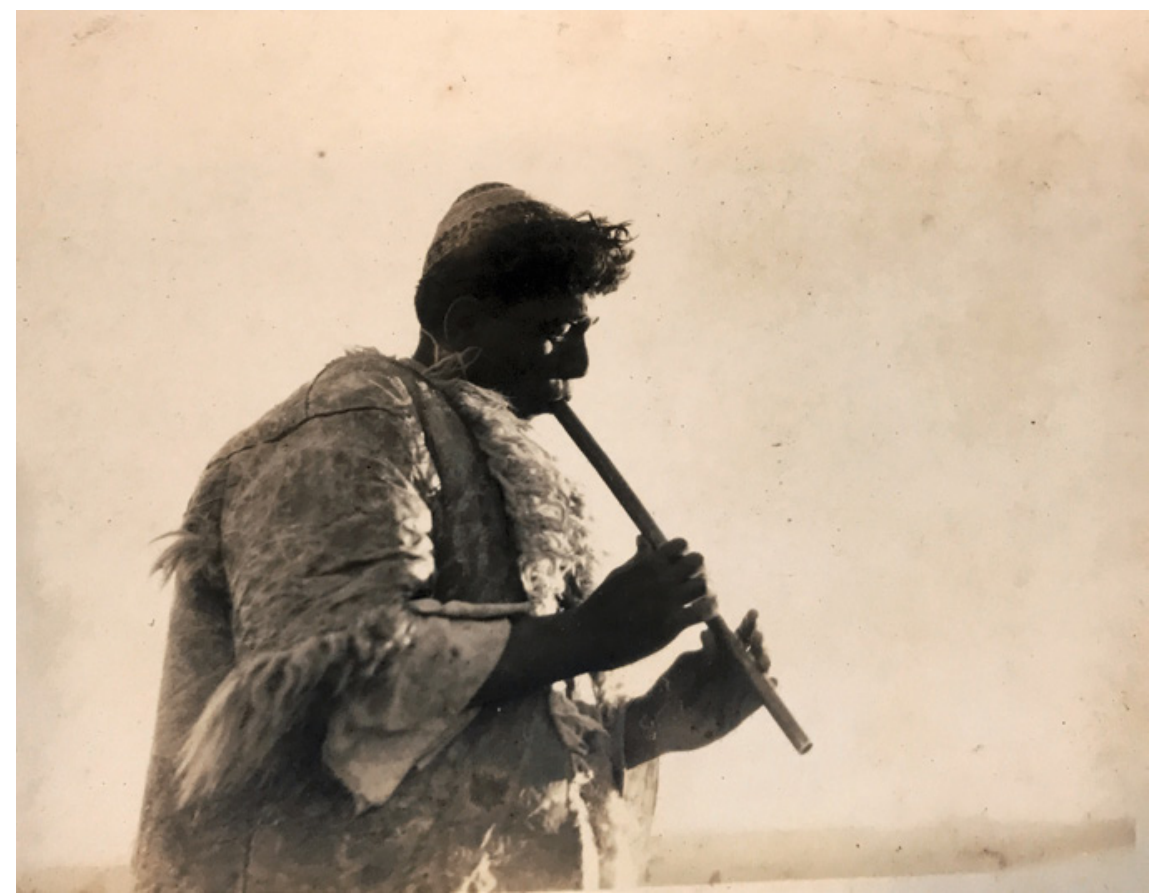

FIGURE 8.6 Untitled, 1921-23. Frank Scholten. A shepherd playing the flute. UBL_NINO_F _Scholten_Fotos_Doos_16_o821, Frank Scholten Collection IMAGE COURTESY OF NINO

break out. ${ }^{58}$ While it is easy to admire the breadth and depth of Scholten's corpus, it would be a romanticisation to assume his class background created equal footings between himself and many of his photographic subjects.

Scholten's village landscapes, particularly Yazūr, on Jaffa's periphery, give us a case study in some of the tensions between the Biblical and the modern. In Figs. 8.7 and 8.8, women and children are gathered in rural costume in the village of Yazūr, just $6 \mathrm{~km}$ east of central Jaffa and near the site of today's Ben Gurion Airport. A rustic prickly pear hedge, trees and a crowd of women and children conjure up the image's biblified settings of its photographic forebears. Were it a film of the 1920s, it would not be difficult to imagine Jesus' imminent arrival. Indeed, reading it as filmic speaks to its fundamentally modern quality.

$5^{8} \quad$ [Author unknown] "Een Nederlander in Nieuw-Palestina" van Houten's Eigen Tijdschrift (April 1934) cut from a magazine and pasted into a notebook of press clippings collected by Scholten on his projects, Scholten collection. With thanks to Maartje Alders for bringing this article to my attention. Frank Scholten Collection, Box marked 'Jan van Duren'. 

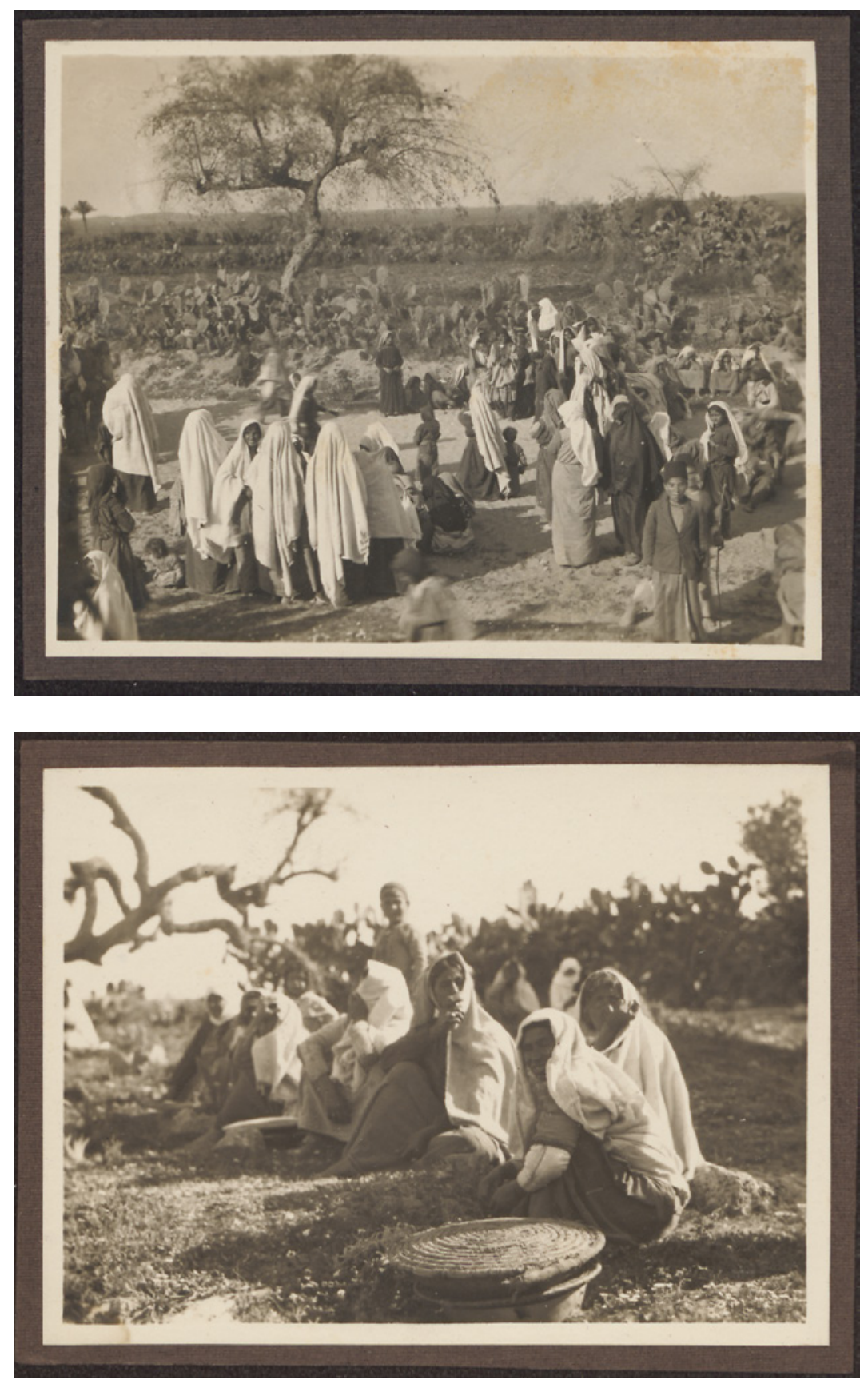

FIGURES 8.7 AND 8.8 Yazur, 1921-23. Frank Scholten, UBL_NINO_F_Scholten _Fotos_Doos_04_04O3 and UBL_NINO_F_Scholten_Fotos_ Doos_04_0025. Frank Scholten Collection

IMAGES COURTESY OF NINO AND UBL 
It seems composed, yet a blurred figure walks through the scene, indicating a spontaneous shot.

Fig. 8.8 speaks to personal dynamics. The three women at the front, despite modesty in front of the camera, look directly into the lens, the one in the front clearly smiling, despite the shadow across her face. There is a sense of familiarity, even friendship. This naturalistic, documentary approach makes us reassess Fig. 8.7. What could have been a staged biblified cliché is indeed a spontaneous documentation of the rural scene, albeit the same subject matter that more biblified photography would privilege. ${ }^{59}$ And yet, within biblification as an imaging convention, such a reading seems difficult to avoid given the weight of previous photographic production.

To help contextualise the social dimensions of such a scene, we might turn our attention to some of the scholarly endeavours of the period. One particular scholar of note was Tawfíq Kana'ān (Canaan,) a medical doctor and anthropologist. While serving in his medical capacity, Kanaān conducted much of his field research into Palestinian folklore and also developed a collection of folk amulets, now housed at the Birzeit Museum. Kana'ān published widely, particularly in the Journal of Palestinian Oriental Society. In the early 1920s, he published a number of scholarly studies that dealt with folk beliefs, for instance Haunted Springs and Water Demons in Palestine $(1920)^{60}$ and Folklore of the Seasons in Palestine (1923), ${ }^{61}$ but continued his writing well into the $1930 \mathrm{os}$.

The work of Kanaān makes an interesting foil for considering class relations in early Mandate Palestine, particularly in the division between middle classes and rural working communities. As a member of the professional class, he was one of a circle of intellectuals who were very much engaged increasingly in modern transnational scholarly practices. His research interests, however, were very much in rural communities and folklore, a culture that was increasingly affected by processes of urbanisation as Stephen Sheehi shows in his chapter. Kanaān's ethnographic work was actively documenting the vanishing rural folklore and practice for posterity, underscoring the vastly different lived experience of modernity that class delineated in Palestine.

59 It is also a typology that came to be reproduced constantly in cinema in the next few years as the first Hollywood biblical epics gained currency through the 1920s. See Sary Zananiri, "From Still to Moving Image: Shifting Representation of Jerusalem and Palestinians in the Western Biblical Imaginary", Jerusalem Quarterly 67 (2016): 64-81.

6o Tawfiq Canaan, "Haunted Springs and Water Demons in Palestine", Journal of Palestinian Oriental Society, vol. I (1920-21): 153-170.

61 Tawfiq Canaan, "Folklore of the Seasons in Palestine", Journal of Palestinian Oriental Society, vol. x (1923). 


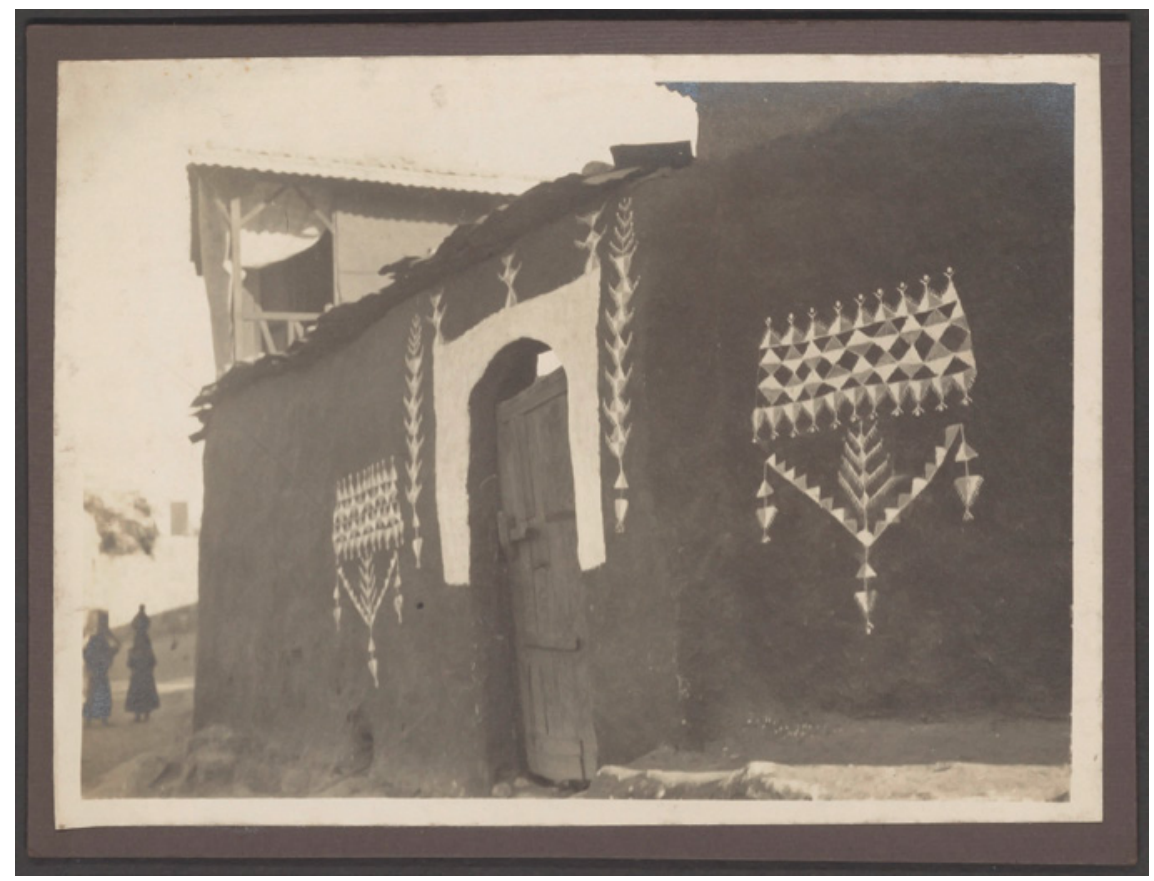

FIGURE 8.9 Untitled, 1921-23. Frank Scholten. A village house decorated with patterns similar to cross stitch. UBL_NINO_F_Scholten_Fotos_Doos_16_o82o. Frank Scholten Collection

IMAGE COURTESY OF NINO AND UBL

The role of photography, and biblified photographic production, has been extensively explored as a by-product of colonial relations and the Western Biblical imaginary, ${ }^{62}$ but the formative moment of the early years of the British Mandate saw a significant shift in demography. The incoming European communities (both Jewish and otherwise) and the urban expansion of cities like Jerusalem $^{63}$ and Jaffa to encompass what were historically Palestinian villages on the urban peripheries into their suburban sprawl, breached, in the physicality of architectural form, the historical distance between urban and rural communities.

This tension between the Biblical and the modern (and perhaps implicitly between the rural and the urban) took on new dimensions in the making of colonial claims. As outlined in the introduction to this volume, Orientalism, like biblification, eschewed the modern, but through a different operation.

62 Nassar, "Biblification' in the Service of Colonialism"; Nassar, "Colonization by Imagination,"; Nassar, "European Portrayals of Jerusalem".

63 Barakat, "The Jerusalem Fellah," 9-12. 


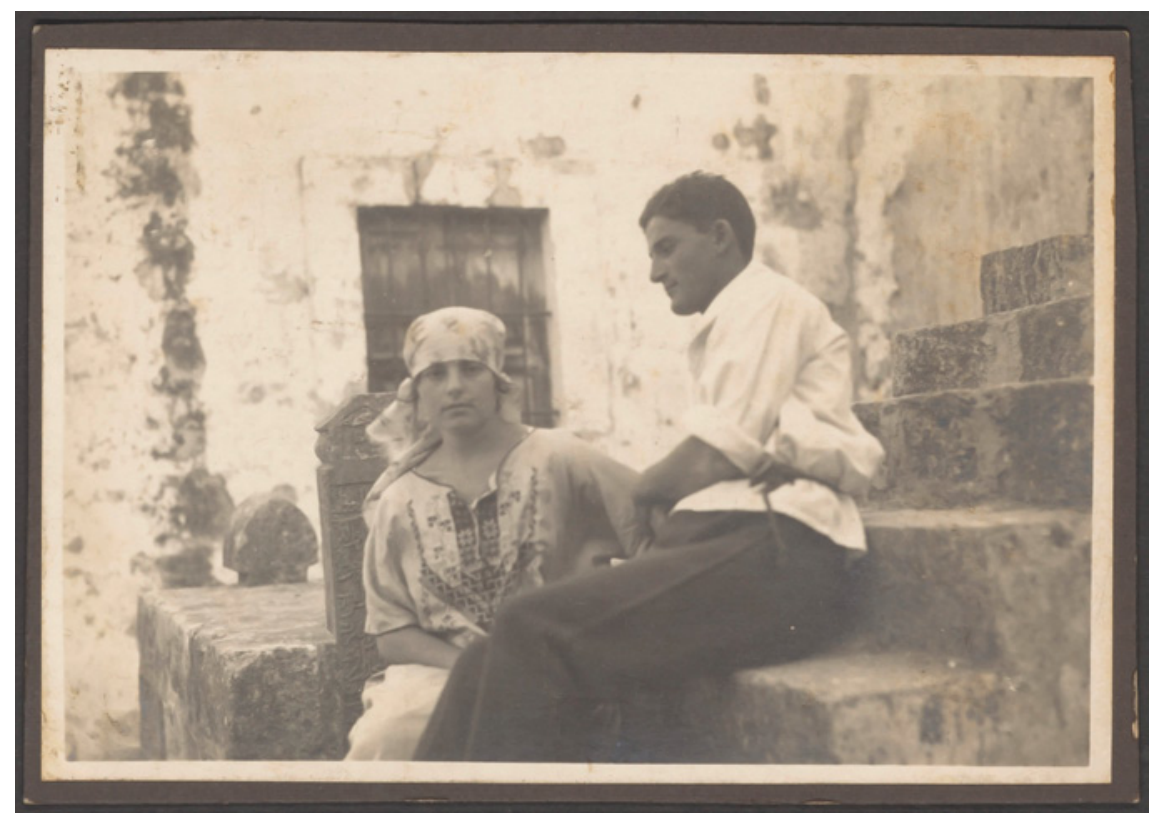

FIGURE 8.10 Tel Aviv, 1921-23. Frank Scholten, UBL_NINO_F_Scholten_Fotos_ Doos_17_o186, Frank Scholten Collection IMAGE COURTESY OF NINO AND UBL

Where biblification relies on the interpretation of the image through a process of familiarisation (that is to say, making the image legible through Biblical narrative), Orientalism is a system that relies on demarcating otherness by the positioning of the 'Orient' and inhabitants against modernity. In very similar ways to biblification, the production, consumption and circulation of Orientalist photographs overlapped with similar demographics to biblified cultural materials: the Western photographic market. But here again, the context of class in both the production and consumption of photography, is important to note.

\subsection{Oriental Bodies}

A photo of a Jewish couple, marked by Scholten as having been taken in Tel Aviv, elaborates on the ways in which Ottoman communalism was morphing (Fig. 8.10). The woman on the left appears in numerous Scholten photographs ranging from her work as nurse in Jewish quarantine stations through to socialising with a predominantly male Zionist social circle. Annotations from other photographs of the couple in the same outfits suggests they had just become engaged. From her head wear and the date of the photograph (1921-23), 
it would seem a safe presumption that she was a Third Aliyah migrant. The context of anti-Jewish pogroms in Eastern Europe as World War I ended, in combination with the restriction of Jewish migration to the US and Western Europe $^{64}$ led a new generation of Jewish migrants to Palestine in the years after the First World War. This photo is particularly telling in terms of the porous social attitudes. She is wearing a thawb, a traditional cross-stitched Palestinian dress, combined with an Eastern European headscarf.

Indigenous photographers in Palestine also took part in similar activities, some offering traditional clothing as 'dress ups' for studio portraits to both tourists and the local population. While the motivations that led Palestinians and foreigners alike to be photographed in such costume may have differences and overlaps as Issam Nassar writes in his chapter of this volume (Figs. 5.6 and $5 \cdot 7$ ), assumptions can be made of both groupings in laying claim to indigeneity. Implicitly, a particular relationship between class and modernity emerges, that gives us a sense of the transnational entanglements constructed by a performance of class.

Very significant questions of cultural appropriation aside, Fig. 8.10 of the woman wearing a thawb is not simply an Ashkenazi testing of whether they want to embody some sort of Palestinian Oriental positioning. It is, in a sense, embodying two completely different subject positions within the same Jewish body, asking whether that body fits within rubrics of 'Palestinian-ness' within identity formation processes so endemic to the period. The thawb itself appears to be made from a mixture of patterns not related to a particular locality or region, though the v-shaped design does on some level reference a typology based in Ramallah designs. ${ }^{65}$ While the thawb points on one level to an assimilationist attitude, it also denotes the popularisation of the thawb as a marker of identity, and perhaps a marker of 'authenticity', as we look to the thawb from Bethlehem worn by the girl discussed in Kopty's chapter at the American Colony (Fig. 9.5).

In this regard, as an image, this underscores amorphous identities that would become actively formalised in the years after this photo was made. The 'honeymoon' context of a new relationship aside, the act of donning the thawb may appear to be a simple gesture of trying new clothing, which certainly has antecedents in Palestinian studio photography, but it belies the complex positioning of Jewish identity within a framework that is at one and the same time part of Europe and also removed from it. This duality is one that had significant

64 Immigration Restriction Act of 1921 in USA and the Alien Act of 1905 in Britain both had significant impacts on Jewish possibilities for emigration from Eastern Europe.

65 I would like to thank Wafa Ghnaim from Tatreez and Tea for this useful information. 
impacts for Jews in Europe. As Grossmann points out, the uneasy positioning of a spectrum of Jewishness in Europe, from ancient and Oriental to modern and European, was not without its consequences in ways the Ashkenazi communities were remediated in photography from Palestine to the West. She notes that Theodor Harburger criticised Karl Gröber's photo book of Palestine in a review, saying that only images of religious Oriental Jews at the Wailing Wall were published in it rather than those images of the Zionist 'new Jew'.66

In looking more broadly at the growing rubrics of orientalisation, the question of class becomes key if we consider Palestine as being the central node in which a series of transnational networks converge. For the Jewish middle classes of Central Europe, the renewal of Jewish culture during the Weimar Republic termed by Michael Brenner as a renaissance saw a particular shift in German perceptions of Jewishness in the rising context of Zionism. ${ }^{67}$

Jewish communities in 1920 Germany were increasingly seen as part of pluralist vision of cosmopolitan culture ${ }^{68}$ and, within the rubric of Zionism, a vanguard of German culture in the so-called 'Holy Land', a trope which would have been familiar to someone like Frank Scholten who had been educated in Berlin.

On the other hand, the development of Jewish identity in the Yishuv and the rise of National Socialism in the 193os required a certain orientalisation of Jewishness to accommodate Zionist ideology. ${ }^{69}$ Zionism required this orientalisation as a means of recouping an 'ancient Jewish past' which would come to be embodied in Jewish Arabs such as Yemenite metal workers, deployed as Zionist cultural diplomacy, ${ }^{70}$ but at the same moment Zionism also embodied that which was fundamentally modern, particularly the narrative of bringing of technology and progress to Palestine. ${ }^{71}$

The mercantile Palestinian middle classes would also be photographed by Scholten both directly, like the portrait of 'T̄sā al-'̄sā with his child ${ }^{72}$ (Fig. 8.11)

66 Rebekka Grossmann, "Negotiating Presences: Palestine and the Weimar German Gaze", Jewish Social Studies 23, no. 2 (2018): 145.

67 Michael Brenner, The Renaissance of Jewish Culture in Weimar Germany (New Haven, CT: Yale University Press 1998).

68 Grossmann, "Negotiating Presences: Palestine and the Weimar German Gaze", 138.

69 Ibid., 16o-161.

70 Nisa Ari, "Competition in the Cultural Sector: Handicrafts and the Rise of the Trade Fair in British Mandate Palestine", in European Cultural Diplomacy and Arab Christians in Palestine, 1918-1948. Between Contention and Connection, eds. Karène Sanchez Summerer and Sary Zananiri (London: Palgrave MacMillan, 2021), 231.

71 Grossmann, "Negotiating Presences: Palestine and the Weimar German Gaze", 15 o.

72 Scholten, Palestine Illustrated, vol. 1, 67, image 128. 


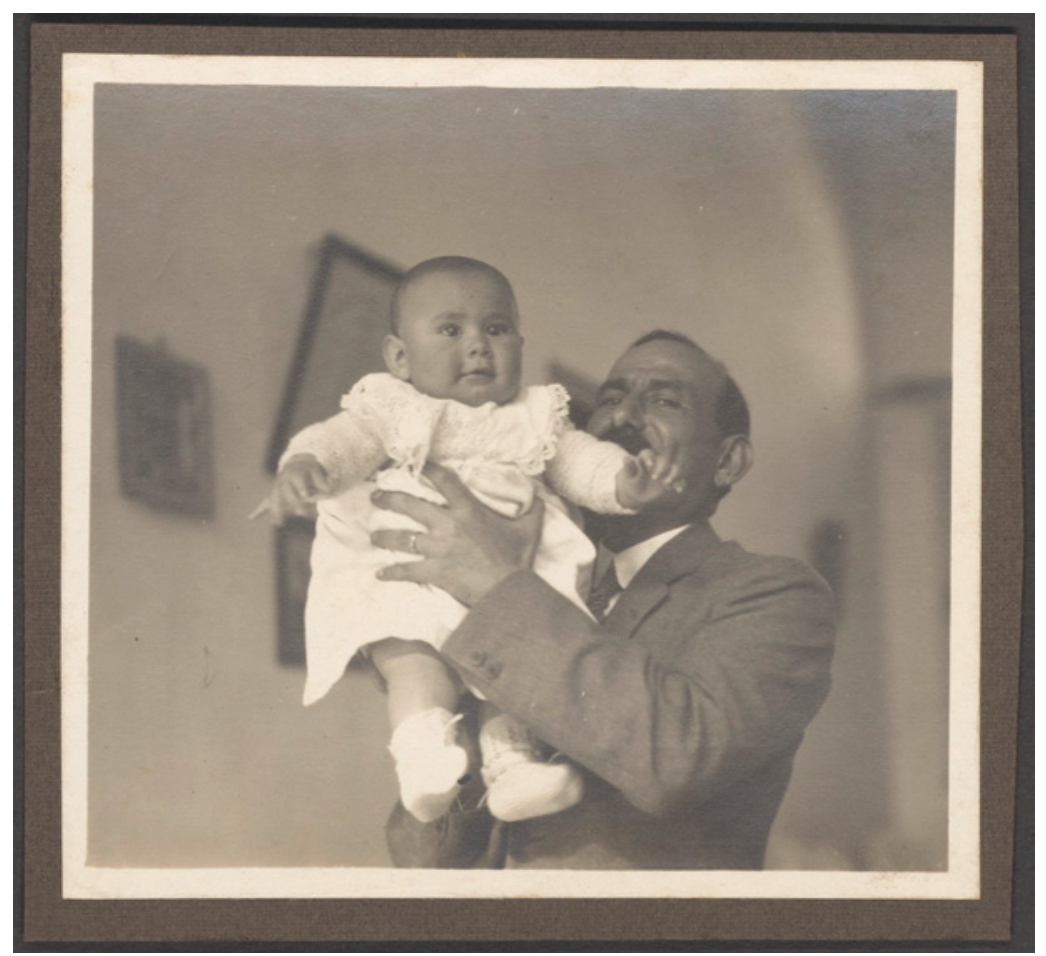

FIGURE 8.11 Untitled, 1921-23. Frank Scholten. Portrait of 'Īsā al-'īsā and son Raja. UBL_NINO_F_Scholten_Fotos_Doos_07_0407, Frank Scholten Collection

IMAGE COURTESY OF NINO AND UBL

or young men enjoying their fast cars (Fig. 8.12) or indirectly, like the lavish interior of a Christian, upper middle-class Palestinian home in Jaffa. ${ }^{73}$

Images of these middle classes differ greatly from the rural and working-class Palestinians who were so often portrayed as embodying the spirit of the Biblical vestige of ancient times. The embodied experience of modernity necessitates consideration of the class connotations of what it meant to live a 'modern' lifestyle. Images such as these point to an Eastern Mediterranean vernacular of modernity, one which was still denoted by the wearing of a tarbush or the use of pointed arches in architecture, despite essentially containing the same furniture and accoutrements an equivalent household in the West might. ${ }^{74}$

73 Scholten, Palestine Illustrated, vol. 2, 67, image 141.

74 Seikaly, Men of Capital: Scarcity and Economy in Mandate Palestine (Stanford: Stanford University Press, 2016): 36-41; Keith David Watenpaugh, Being Modern in the Middle East: 


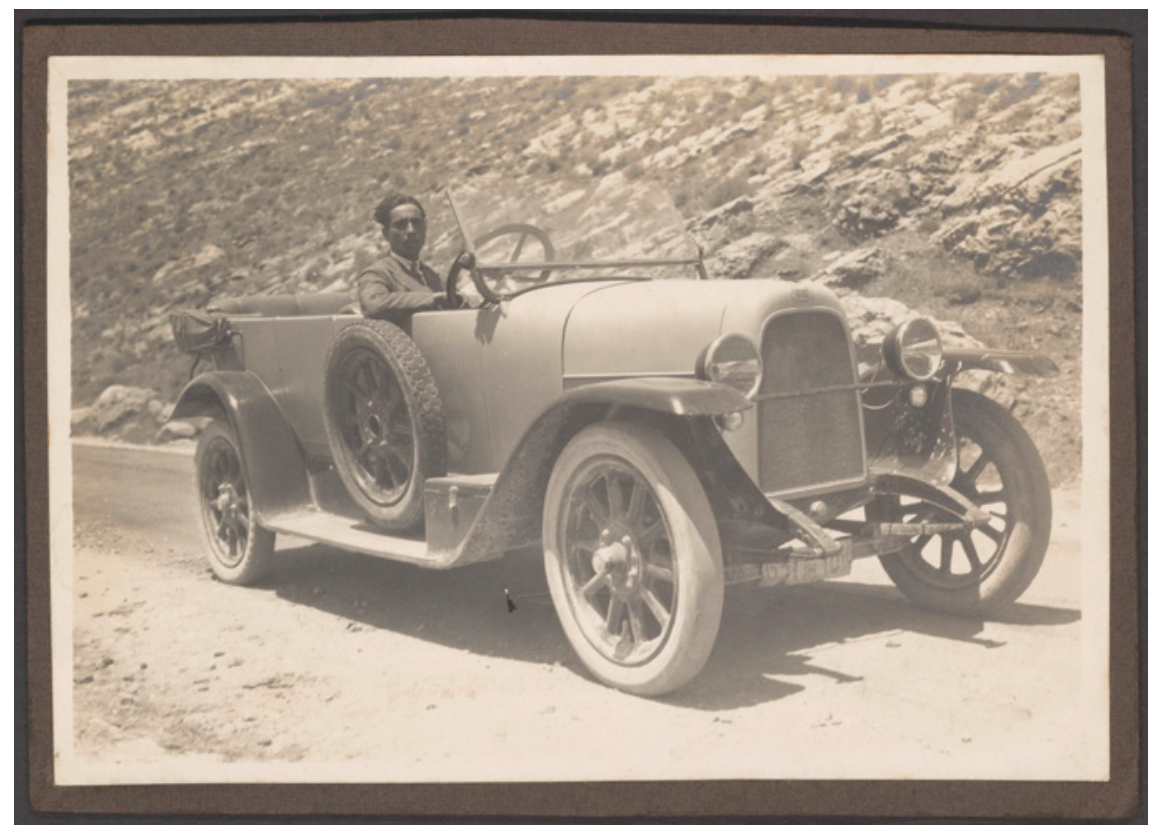

FIGURE 8.12 Untitled, 1921-23. Frank Scholten. UBL_NINO_F_Scholten_Fotos_ Doos_17_o215, Frank Scholten Collection IMAGE COURTESY OF NINO AND UBL

Taken in conjunction with the series of images about Palestinian industry, particularly the lumber, soap and orange exports that Scholten imaged, ${ }^{75}$ we see a world which is connected through commerce and, within a few years of Scholten's time in Palestine, would establish important multinational financial institutions like the Arab Bank (founded 1930) and later Intra Bank (founded 1951, but with antecedents in the Mandate period) by Yusif Baydas, son of the Nahda literary figure Khalil Baydas. This 'orientalised' iteration of modernity at once shows the results of participation in international trade and commerce, but also the cultural fractures between urban and rural life, the growing middle class and, implicitly, the continuities of the pre-war legacies of the Tanzimat Reforms.

As Keith Watenpaugh outlines in the first chapter of his book Being Modern in the Middle East, the ethnically and confessionally diverse middle classes of the late Ottoman period was small, but disproportionately influential. Its

Revolution, Nationalism, Colonialism, and the Arab Middle Class (Princeton: Princeton University Press, 2012), chapter 1.

75 Scholten, Palestine Illustrated, vol. 2, images 118-129 and 231-259. 
relationships to technology, liquid financial assets and its privileged relationship to education ${ }^{76}$ had come about through confessionally-specific affiliations that tethered communities to various European states through various modes of cultural diplomacy, for example in the arena of education. This shows yet another layer to the multiplicity of networks embedded in early Mandate Palestine.

The fact that Scholten referred slightly differently to each of the ethnic and confessionally diverse communities of Palestine in the different language versions of the first volume of his books once again underscores these colonial relationships. But it also points to his nuanced understanding of broader geo-political relationships enabled by European cultural diplomacy, in which those communities are related back to his Western readership through such affiliations.

\subsection{Taxonomising a Colonial Landscape}

Scholten's photographic collection shows us a world in which British colonial rule brought new populations into the already diverse post-Ottoman landscape. He shows us British soldiers, from Tommies to Gurkhas, but also French and American troops. The upsurge in Eastern European anti-Semitism in the early 1920 sould bring new and significantly larger migrations of European Jews as part of the Third Aliyah. By the early 1920s, several generations of modern, mercantile, middle class and globally connected Palestinians ${ }^{77}$ had engaged with the world well beyond the former Ottoman empire's borders, taking part in international discussions about nationalist aspirations with former compatriots who were now neighbours in Syria, Lebanon and Egypt and very much engaged with the European powers who had established and cemented their presences in nineteenth century Palestine.

This deft conjuring of landscapes further afield is perhaps most visible in images of the incoming South Asian communities Scholten photographed. Gurkha regiments had been part of the British army since the early nineteenth century. By World War I, they comprised eleven regiments, each greatly expanded with extra battalions, numbering a total of 200,00o men. ${ }^{78}$ The Gurkhas were involved in General Allenby's campaign in Palestine and

76 Watenpaugh, Being Modern in the Middle East, 26-27.

77 For instance, in the mother of pearl trade, which saw Palestinian trading communities developed in Paris, Manchester, Kiev, Port-au-Prince and Manila see Jacob Norris, "Exporting the Holy Land: Artisans and Merchant Migrants in Ottoman-Era Bethlehem", Mashriq \& Mahjar 1, no. 2 (2013).

78 Alan Axelrod and Michael Dubowe, Mercenaries: A Guide to Private Armies and Private Military Companies (Thousand Oaks, CA: CQ Press, 2014), 70. 


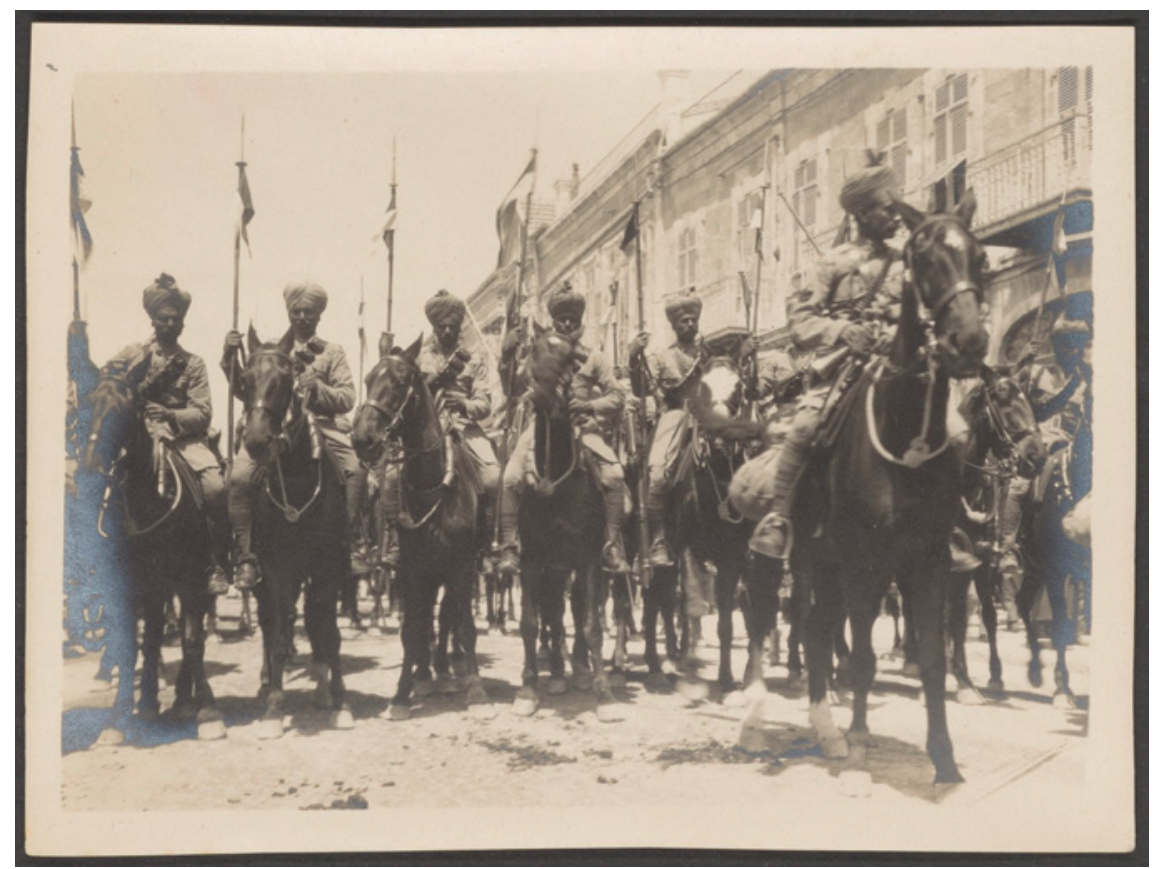

FIG URE 8.13 Untitled, 1921-23. Frank Scholten. Gurkhas in Jerusalem leaving for Nabī Mūsā. UBL_NINO_F_Scholten_Fotos_Doos_O2_OO74, Frank Scholten Collection IMAGE COURTESY OF NINO AND UBL

W.T. Massey describes the loss of South Asian lives euphemistically in terms of 'sacrifice' in the British capture of Jerusalem. ${ }^{79}$ The proliferation of images showing South Asian participations in the Nabi Musa festival give us a sense of other complex encounters, which require considerable further research at a later stage.

The changing nature of Nabī Mūsā from a religious festival to a nationalist expression exemplified by the riots of 1920 raises quite a series of questions: how did South Asian troops participating in Nabī Mūsā relate to shifts in local politics in Palestine? Did they view the growth of Palestinian nationalism through the lens of Indian politics, particularly the Lucknow Pact between the Indian National Congress and the Muslim League in 1916 and the civil unrest of the early 1920s? Did this create transnational anti-colonial solidarities or were the Gurkhas simply regarded by Palestinians as just another arm of the British

79 See William Thomas Massey, How Jerusalem Was Won Being the Record of Allenby's Campaign in Palestine (1919), Ebook available via https://www.gutenberg.org/cache/ epub/10o98/pg10o98.html, accessed October 18, 2019. 


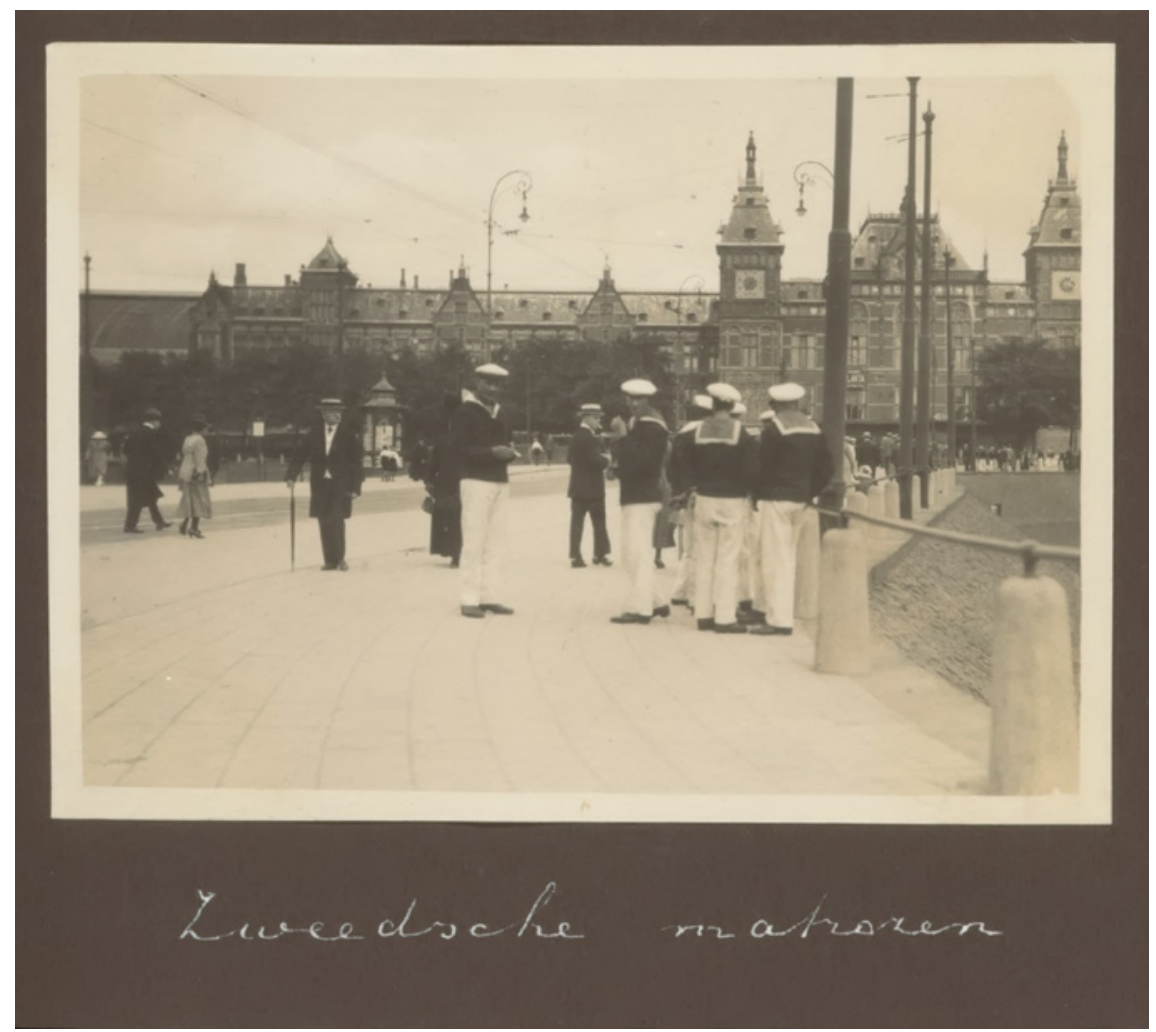

FIGURE 8.14 Zweedsche matrozen, 1918-19. Frank Scholten. 'Swedish sailors' at Amsterdam Centraal Station. Part of his album 'Amsterdam'. UBL_NINO_F_Scholten_ Netherlands_Amsterdam_o1o, Frank Scholten Collection IMAGE COURTESY OF NINO AND UBL

occupation of Palestine? Sadly, these questions of colonial mobility and their impacts must be left for further research.

\subsection{A Queer Lens?}

What the images of the Gurkhas and other troops show is how the apparatus of the Great War, and its aftermath, facilitated colonial mobility. Scant evidence exists of Scholten's relationships in Palestine beyond photographic records and brief notations in postcards. However, inferring from legal records in the Netherlands, which document his sexual encounters with military men at Amsterdam Centraal Station, ${ }^{80}$ we might propose that the proliferation of various populations of troops in Palestine also provided opportunities for

8o Van der Meer, Jonkheer mr.Jacob Anton Schorer (1866-1957), 159. 
homosocial interactions, which cut across class divides. This thesis is certainly supported by the amount of images of military men and homosocial spaces in his Palestinian photographs. The images of Nissan Huts at the British military base in Sarafand, one of the most significant bases in Palestine, certainly seem to be anomalous within more typical readings of Palestine amongst Western photographers, even amongst the plethora of soldiers' albums from World War I and the years afterwards.

The time that Scholten spent in Palestine, therefore, can be seen as a period of post-Ottoman entrenchment of the British, very much a world that was undergoing radical shifts and changes in relation to demography, administration and culture, but also one in which Ottoman imperial mobility across the Eastern Mediterranean was changing to a globalised framework of British colonial mobility and newly formed borders framed new cultural identifications.

We can infer from repeated images of people in the photographic collection, that Scholten had a wide circle of friends and acquaintances in Palestine. Certainly, from his published works, we can also gather his nuanced understanding of post-Ottoman communal structures. Apart from a biographical article by Teresa Kwiecien ${ }^{81}$ and another short study by me, ${ }^{82}$ there are but a few secondary sources on Scholten, generally in studies of other personalities such Jacob Israël de Haan, ${ }^{83}$ Jacob Schorer ${ }^{84}$ or more general studies of Dutch histories of sexuality that deal with the years in Europe preceding his time in Palestine. Consideration of these studies paints a strong queer subtext to the collection.

Homosexual relations had been decriminalised across the Ottoman Empire in 1858 as part of the Tanzimat Reforms, although they would be recriminalised by the British first with anti-Sodomy legislation in 1927 and then the banning homosexual relations in $1936 .{ }^{85}$ Analysis of court records from the 1930 and 40s, during the period in which homosexuality had been recriminalised, certainly point to cross-communal homosexual relations as not uncommon. ${ }^{86}$

$81 \quad$ Kwiecień, "Frank Scholten".

82 Zananiri, "Frank Scholten: landschap in het Brits Mandaat Palestina".

83 Ludy Giebels, produced a number of works on De Haan, which have mentions of Scholten, including a photo he had taken of De Haan in Jericho. Likewise, Scholten is mentioned in J. Fontijn, Onrust: Het leven van Jacob Israël de Haan, 1881-1924 (Amsterdam: De Bezige Bij, 2015).

84 Van der Meer, Jonkheer mr. Jacob Anton Schorer (1866-1957).

85 Orna Alyagon Darr, "Narratives of 'Sodomy' and 'Unnatural Offences' in the Courts of Mandate Palestine (1918-1948)," published online by Cambridge University Press (2017): 241-242.

86 Orna Alyagon Darr, Plausible Crime Stories (Cambridge: Cambridge University Press, 2019): $31-32$. 

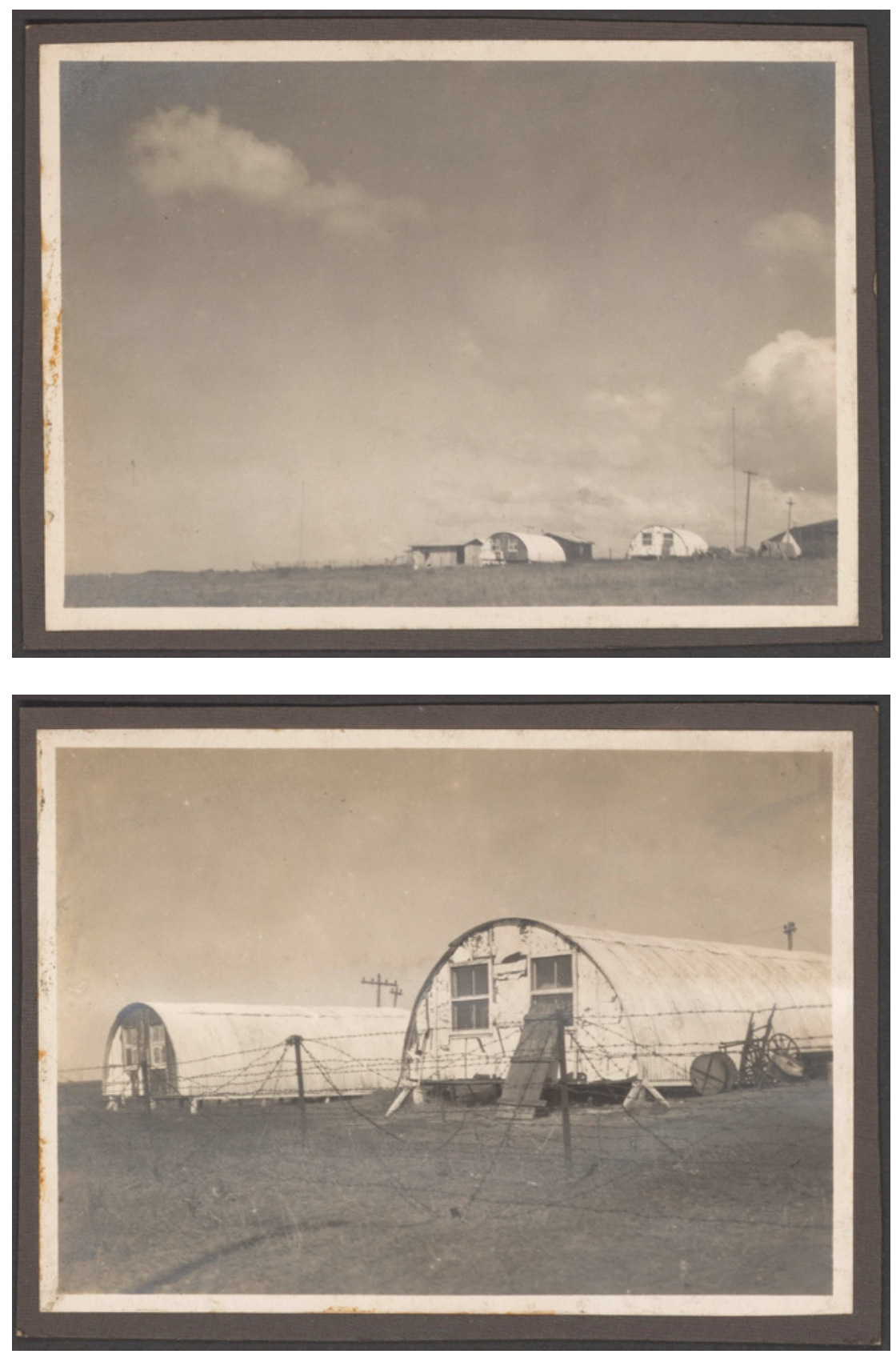

FIGURE 8.15 AND 8.16

Untitled [marked Sarafand], 1921-23. Frank Scholten. Nissan huts used as soldiers' barracks at the British Military Base in Sarafand. UBL_NINO_F_Scholten_Fotos_Doos_16_1005 and UBL_NINO_F _Scholten_Fotos_Doos_16_10o9, Frank Scholten Collection IMAGES COURTESY OF NINO AND UBL 
Given the gaps in legal records for the early 1920s, we can but infer the social situation from later prosecutions and hope that further research on the topic through other documents like memoirs will be undertaken in the future.

In the arena of sexual diversity during the early 1920 s two points stand out. Firstly, that legal (and, at least to some degree, social) attitudes to homosexuality were subjected to similarly changing forces and codification as the other arenas of society. Secondly, that the queer networks within the complicated ethno-confessional context of the period, at least to some degree cut across communal divides, as the relationship between de Haan and his partner 'Adil Aweidah attest.

The queer subtext to much of the Scholten collection taken at a surface level, may appear to contradict the history of Orientalist and biblified imaging. However, the repeated images of David in Scholten's found images, for instance, cut across different eras, art styles, mediums and artists in a comparative mode. While this underscores a scholarly comparison on an art historical level, it also speaks to modes of transnational and transcultural comparison that attempt to come to grips with the differing treatment of the Biblical figure through a queer lens across time, culture and geography, effectively threading across otherwise disparate categories.

In many ways, however, these queer subtexts uphold Scholten's gestures towards modernity. This, taken with intellectual milieu in which Scholten mixed, the influence of scholarly methodologies and the new theories of sexuality he was exposed to, we can begin to understand the complexity of Scholten's project in Palestine.

Taken in conjunction with his conversion to Catholicism and the art historical materials present in his collected images, we might infer an engagement with André Rafflovich's Uranism et Unisexualité of 1896. A liberal Catholic, Rafflovich argued that same-sex desire had given rise to much of Western high culture, making inverts (a historical British term of the period for homosexuals) the ideal priest. Invoking Platonic ideals, he argued that occasional homosexual lapses were sins, but not grievous errors. ${ }^{87}$

While biblification and orientalisation, both in Europe and the Arab World, were used to delineate the limitations of civility, the authority of classicism, with its implications of rationality would, as per Rafflovich, buttress colonial notions of 'Western Civilisation' and hence colonial power dynamics. In the Scholten collection, their conflation with biblification and its latent

87 For more information see Frederick S. Roden, "Queer Christian: The Catholic Homosexual Apologia and Gay/Lesbian Practice", International Journal of Sexuality and Gender Studies 6, no. 4 (2001): $25^{2}$. 


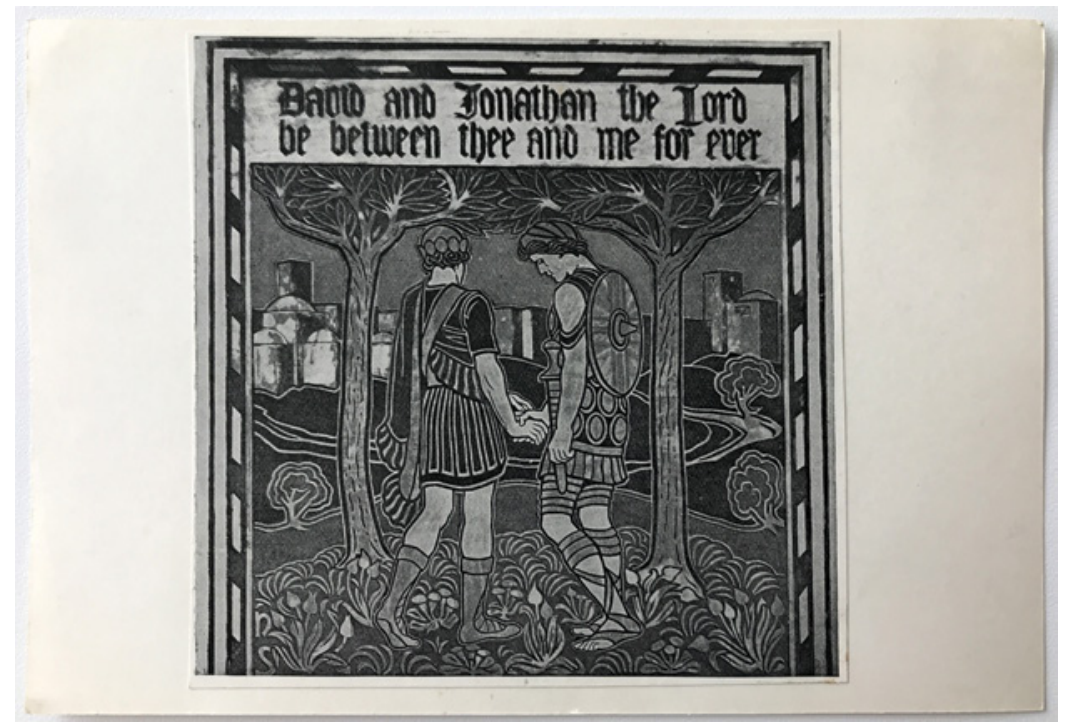

FIGURE 8.17 David and Jonathan, 1891. George Heywood Sumner, published in 'The Studio', 1891. From the 'found images' collection, Frank Scholten Collection, Box A8

IMAGE COURTESY OF NINO

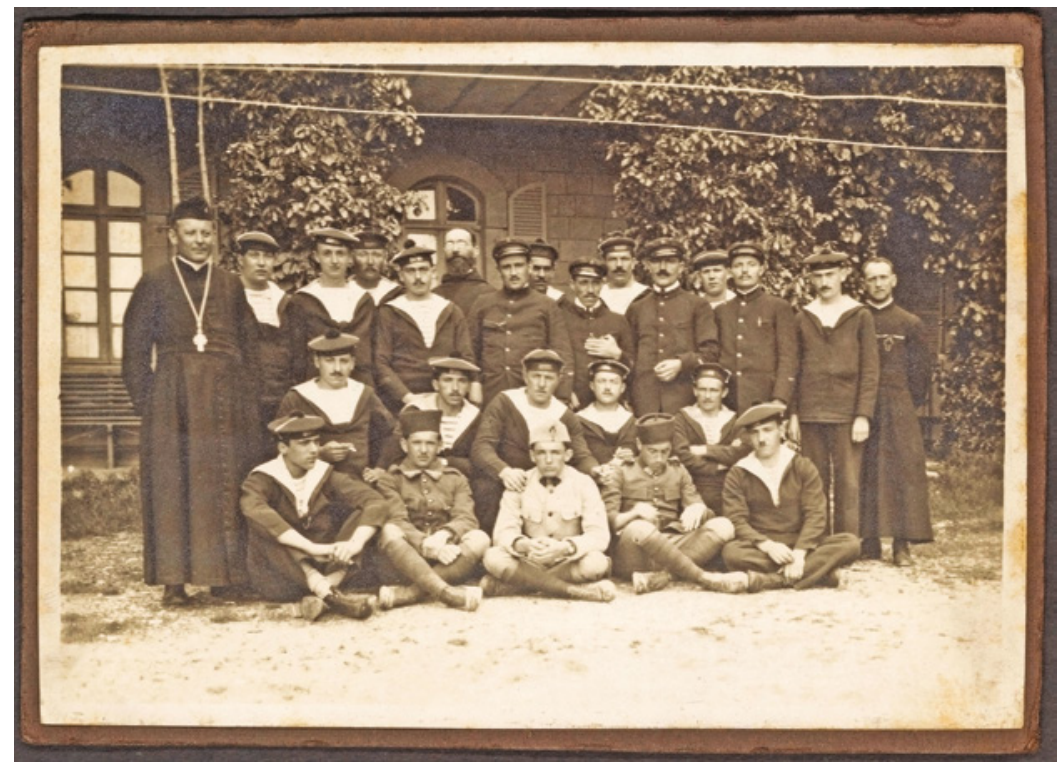

FIGURE 8.18 Untitled [French soldiers in Jerusalem], 1921-23. Frank Scholten. UBL_ NINO_F_Scholten_Fotos_Doos_17_O216, Frank Scholten Collection IMAGE COURTESY OF NINO AND UBL 
homoeroticism undermines this. Instead, we might see him as implicitly attempting to reconcile or create a complicated confluence between classicism, biblification, Orientalism and modernity.

Scholten's lens and what might be termed a 'pilgrimage of redemption' to Palestine after his legal troubles in the Netherlands, gives us a unique insight into the nuances of post-Ottoman communalism from the very particular lens of Dutch pillarisation. This sensitive understanding of the social mechanics of communal spheres in combination with a queer lens gives us a sense of cultural porosities that the early Mandate engendered, but also a sense of a modern sexological approach that underpins his attitude.

\section{5}

\section{Conclusion}

The Frank Scholten Collection, through its complex study of communities in Palestine and its attempts to apply modern academic methodologies of the day, stands testament to a period of significant cultural and social reorganisation, both in Palestine and Europe. What Scholten's methodology and the collection he left behind show is a world in which modernity was fundamental to creating descriptive taxonomies, a process of ordering the world through scholarly engagement.

While the lack of detailed textual information beyond postcard correspondence and image annotations hinders a complete picture of Scholten's corpus, the picture that does emerges from the Scholten collection is a complex one. From the photographic and found image annotations, we can see he drew on a diversity of scholarly fields from early medicalised and theological theories of sexuality, Western art historical methodologies, Palestinian and Biblical history, and theological enquiries into text. On a photographic level, we see evidence that he was acutely aware of the different ethno-confessional affiliations in local communities and within his publications we see an understanding of how those communities had affinities with the Western powers active in the region. However, on a personal level we can but make inferences from the Scholten collection on the ways he might have drawn, perceived or experienced parallels between different social systems of organisation, like Dutch pillarisation and the Ottoman Millet system, both products of their respective nineteenth century modern social policies.

This complicated matrix of taxonomies generated by Scholten engages carefully with histories of biblified and Orientalist imaging of the 'Holy Land'. His lens illustrates how biblification and Orientalism were produced by modernity, but also how the three interacted, producing an intimate portrait of the 
establishment of the British Mandate and early Mandate society. This interaction gives us a useful framework for analysing the shifting ethnic, confessional and class diversity of Palestine during the establishment of the British Mandate period in demarcating communities. But more importantly, it serves our understanding of the shifting contexts of modernity that demonstrates the production of the framework of the Biblical Moderne in the portrayal of local communities.

This is further complicated by the queerness of Scholten's lens. Liberal Catholic thought around homosexuality may have been an attractive factor in his conversion, but the social dynamics around sexuality, and implicitly class, is evident in the repeated images of handsome men, particularly in the military, as well as homosocial spaces like male dorm rooms and workplaces. These images hint at the ways Scholten may have operated socially in terms of liaisons with other men, but also the ways in which his homosexuality may also have transgressed communal boundaries and contributed to his understanding of the different 'compartments' in social systems like pillarisation or the Ottoman millet.

Scholten shows us a version of Palestinian society that connects to the world through many networks, but also a context of complexity that gave rise to significantly less nuanced identities as the nationalist aspirations of the period progressed, most embodied by the disastrous consequences of British colonial rule.

\section{Bibliography}

\section{Primary Sources}

The Frank Scholten Collection, Netherlands Institute for the Near East, Leiden University Library.

\section{Secondary Sources}

Ari, Nisa. "Competition in the Cultural Sector: Handicrafts and the Rise of the Trade Fair in British Mandate Palestine." In European Cultural Diplomacy and Arab Christians in Palestine, 1918-1948. Between Contention and Connection, edited by Karène Sanchez Summerer and Sary Zananiri. London: Palgrave MacMillan, 2020.

Axelrod, Alan and Michael Dubowe. Mercenaries: A Guide to Private Armies and Private Military Companies. Thousand Oaks, CA: CQ Press, 2014.

Barakat, Rana. "The Jerusalem Fellah: Popular Politics in Mandate-Era Palestine." Journal of Palestine Studies 46, no. 1 (2016): 7-19. 
Barakat, Rana. "Urban planning, colonialism and the Pro-Jerusalem Society." Journal of Palestine Studies 65, no. 1 (2016): 22-34.

Barkey, Karen and Gavrilis, George. "The Ottoman Millet System: Non-Territorial Autonomy and its Contemporary Legacy", Ethnopolitics 15, no. 1 (2016): 24-42.

Beška, Emanuel From Ambivalence to Hostility: The Arabic Newspaper Filasțin And Zionism, 1911-1914. Slovak Academic Press: Bratislava, 2016.

Bratt, James D. Abraham Kuyper: Modern Calvinist, Christian Democrat. 2nd Impression. Grand Rapids, Mich.: Eerdmans, 2013.

Brenner, Michael. The Renaissance of Jewish Culture in Weimar Germany. New Haven, CT: Yale University Press, 1998.

Canaan, Tawfik. "Haunted Springs and Water Demons in Palestine." Journal of Palestinian Oriental Society vol. 1 (1920-21): 153-170.

Canaan, Tawfik. "Folklore of the Seasons in Palestine." Journal of Palestinian Oriental Society vol. 3, no. 1 (1923): 21-35.

Darr, Orna Alyagon. "Narratives of 'Sodomy' and 'Unnatural Offences' in the Courts of Mandate Palestine (1918-1948)." Law and History Review 35, no.1 (2017): 235-26o.

Darr, Orna Alyagon. Plausible Crime Stories. Cambridge: Cambridge University Press, 2019.

Deam Tobin, Robert. Peripheral Desires: The German Discovery of Sex. Philadelphia: University of Pennsylvania , 2015.

"Een Nederlander in Nieuw-Palestina", van Houten's Eigen Tijdschrift. April 1934.

Fontijn, J. Onrust: Het leven van Jacob Israël de Haan, 1881-1924. Amsterdam: De Bezige $\mathrm{Bij}, 2015$.

Giddens, Anthony. The Consequences of Modernity. Cambridge: Polity Press, 1991.

Grossmann, Rebekka. "Negotiating Presences: Palestine and the Weimar German Gaze." Jewish Social Studies 23, no. 2 (2018): 137-172.

Grossmann, Rebekka. "Image Transfer and Visual Friction: Staging Palestine in the National Socialist Spectacle." The Leo Baeck Institute Yearbook 64, no. 1 (2019):19-45. Haan, Jacob Israel de and W. Simons. Pijpelijntjes. Amsterdam: Van Cleef, 1904.

Halaby, Awad. "Islamic Ritual and Palestinian Nationalism: al-Hajj Amin and the Prophet Moses Festival in Jerusalem, 1921 to 1936." In Jerusalem Interrupted: Modernity and Colonial Transformation 1917-Present, edited by Lena Jayyusi, 139-152. Northampton, MA: Interlink Publishing: 2013.

Hellemans, Staf. "Pillarization ('Verzuiling'). On Organized 'Self-Contained Worlds' in the Modern World", The American Sociologist 51 (2020): 125.

Hill, Darryl B. "Sexuality and Gender in Hirschfeld's Die Transvestiten: A Case of the 'Elusive Evidence of the Ordinary'." Journal of the History of Sexuality 14, no. 3 (2005): 316-332.

Jayyusi, Lena. ed. Jerusalem Interrupted: Modernity and Colonial Transformation 1917-Present. Northampton, MA: Interlink Publishing: 2013. 
Kwiecień, Teresa Lidia. “Frank Scholten.” Depth of Field 40 (December 2008), Article No.: 5. https://depthoffield.universiteitleiden.nl/2540fo5en/.

"Life in Palestine." Times (London, England) 26 Feb. 1924. The Times Digital Archive. Web.

Linder, Douglas O. "The Trials of Oscar Wilde: An Account." Famous Trials https:// www.famous-trials.com/wilde/327-home. Accessed February 22, 2020.

Massey, William Thomas. How Jerusalem Was Won Being the Record of Allenby's Campaign in Palestine (2003). Available online via http://www.gutenberg.org/ cache/epub/10o98/pg10og8-images.html.

Mazza, Roberto. Jerusalem from the Ottomans to the British. London: I.B. Tauris, 2009.

Meer, T. van der. Jonkheer mr. Jacob Anton Schorer (1866-1957) Een biografie van homoseksualiteit. Amsterdam: Schorer Boeken, 2007.

Nasser, Issam. "Biblification' in the Service of Colonialism: Jerusalem in Nineteenthcentury Photography." Third Text 20, no. 374 (2006): 317-326.

Nassar, Issam. “Colonization by Imagination." In City of Collision, edited by P. Misselwitz, T. Rieniets, Z. Efrat, R. Khamaisi and R. Nasrallah, 222-226. Basel: Birkhäuser, 2006.

Nassar, Issam. "European Portrayals of Jerusalem: Religious Fascinations and Colonialist Imaginations." Lewiston, NY: Edwin Mellen Press, 2006.

Norris, Jacob "Exporting the Holy Land: Artisans and Merchant Migrants in Ottoman-Era Bethlehem", Mashriq \& Mahjar 1, no. 2 (2013).

Phoning Photos by Wire: 5 Minutes to Send and 28 Minutes to Develop a Picture, Current Opinion (1913-1925); New York vol. LXXVII, (Jul-Dec 1924): 88.

Post, H. Pillarization: An analysis of Dutch and Belgian society. Aldershot [etc.]: Avebury, 1989.

Roden, Frederick. "Queer Christian: The Catholic Homosexual Apologia and Gay/ Lesbian Practice." International Journal of Sexuality and Gender Studies 6, no. 4 (Oct. 2001): 251-265.

Rubinstein, William., and Jolles, Michael A. The Palgrave Dictionary of Anglo-Jewish History. London: Palgrave MacMillan UK, 2011.

Sanchez Summerer, Karène and Zananiri, Sary., eds., European Cultural Diplomacy and Arab Christians in Palestine, 1918-1948. Between Contention and Connection. London: Palgrave Macmillan, $202 \mathrm{O}$.

Scholten, François. La Palestine Illustrée: Tableau Complet de la Terre Sainte par la Photographie, Évoquant les Souvenirs de la Bible, du Talmud et du Coran, et se Rapportant au Passé comme au présent, Vol I La porte d'entrée - Jaffa Vol II. Jaffa la Belle. Paris: Jean Budry \& Co., 1929.

Scholten, Frank. Palästina - Bibel, Talmud, Koran. Eine vollständige Darstellung aller Textstellen in eigenen künstlerischen Aufnahmen aus Gegenwart und Vergangenheit des Heiligen Landes. Bd. I: DIE EINGANGSPFORTE. JAFFA. Mit 449 Abbildungen in 
Kupfertiefdruck, Bd.II:JAFFA, DIE SCHÖNE. Mit 371 Abbildungen in Kupfertiefdruck. Stuttgart: Hoffmann, 1930.

Scholten, Frank and G. Robinson Lees, eds. Palestine Illustrated including References to Passages Illustrated in the Bible, the Talmud and the Koran, Vol.1 Gate of Entrance, Vol. 2 Jaffa the Beautiful. London: Green Longmans, 1931.

Scholten, Frank. Palestina: Bijbel, Talmud, Koran. Een volledige illustratie van alle teksten door middel van eigen artistieke foto's uit het heden en verleden van het Heilige Land De toegangspoort Jaffa. Leiden: Sijthoff, 1935.

Schweitzer, Albert., trans. W. Montgomery, The Quest for the Historical Jesus: A Critical Study of its Progress from Reimarus to Wrede. London: Adam and Charles Black, 1911.

Seikaly, Men of Capital: Scarcity and Economy in Mandate Palestine. Stanford: Stanford University Press, 2016.

Sharkey, Heather "History Rhymes? Late Ottoman Millets and Post-Ottoman Minorities in the Middle East", International Journal of Middle East Studies 50, no. 4 (2018): 76o-764.

Sheehi, Stephen. The Arab Imago: A Social History of Portrait Photography 1860-1910. Princeton: Princeton University Press, 2016.

Stanton, Andrea L., “This Is Jerusalem Calling': State Radio in Mandate Palestine”, Jerusalem Quarterly 50, no. 2 (2012): 6-22.

Tamari, Salim. "The War Photography of Khalil Raad: Ottoman Modernity and the Biblical Gaze." Jerusalem Quarterly $5^{2}$ (2013): 25-37.

The British Journal of Photography, February 29, 1924.

The Universe The Catholic Newspaper, February 29, 1924.

Turjman, Ihsan Salih, and Salim Tamari, Year of the locust: a soldier's diary and the erasure of Palestine's Ottoman past. Berkley: University of California Press, 2015.

Watenpaugh, Keith David. Being Modern in the Middle East: Revolution, Nationalism, Colonialism, and the Arab Middle Class. Princeton: Princeton University Press, 2012.

Waterschoot, Jos van, Bert Sliggers and Marita Mathijsen. Onder De Toonbank: Pornografie En Erotica in De Nederlanden. Amsterdam: Uitgeverij van Oorschot, 2018.

Wilde, Oscar. https://www.famous-trials.com/wilde/327-home.

Zananiri, Sary. "From Still to Moving Image: Shifting Representation of Jerusalem and Palestinians in the Western Biblical Imaginary." Jerusalem Quarterly 67 (2016): 64-81. Zananiri, Sary. "Frank Scholten: landschap in het Brits Mandaat Palestina." Fotografische Geheugen (December 2018). 